\title{
Assessment of emerging energy-efficiency technologies for the pulp and paper industry: A technical review
}

\author{
Lingbo Kong ${ }^{\text {a, b, c, * }, \text { Ali Hasanbeigi }}{ }^{\text {, }}$, Lynn Price ${ }^{b}$ \\ ${ }^{\mathrm{a}}$ Tianjin Key Laboratory of Pulp and Paper, Tianjin University of Science and Technology, Tianjin \\ 300457, China \\ ${ }^{\mathrm{b}}$ China Energy Group, Energy Analysis and Environmental Impacts Division, Lawrence Berkeley \\ National Laboratory, Berkeley, CA94720, USA \\ ${ }^{\mathrm{c}}$ State Key Laboratory of Pulp and Paper Engineering, South China University of Technology, Guangzhou, \\ Guangdong 510640, China
}

\begin{abstract}
The pulp and paper industry accounts for approximately 5 percent of total industrial energy consumption and contributes 2 percent of direct carbon dioxide $\left(\mathrm{CO}_{2}\right)$ emissions from industries. World paper and paperboard demand and production are increasing significantly, leading to an increase in this sector's energy use and $\mathrm{CO}_{2}$ emissions. Although current studies identify a wide range of energy-efficiency technologies that have already been commercialized for the pulp and paper industry, information is limited or scattered regarding new energy-efficiency technologies that are not yet fully commercialized. Development of emerging or advanced energy-efficiency technologies and their deployment in the market will be crucial for this industry's mid- and longterm energy saving and climate change mitigation strategies. This paper compiles available information on energy savings, environmental and other benefits, costs, and commercialization status for 25 emerging technologies to reduce the energy use and $\mathrm{CO}_{2}$ emissions. The purpose is to provide a well-structured comprehensive review on these emerging energy-efficiency technologies for engineers, researchers, investors, policy makers, pulp and/or paper companies, and other interested parties.
\end{abstract}

Keywords: Emerging energy-efficiency technology; Energy saving; $\mathrm{CO}_{2}$ emissions; Pulp and paper industry

\section{Introduction}

The pulp and paper industry accounts for approximately 5 percent of total industrial final energy consumption and 2 percent of direct carbon dioxide $\left(\mathrm{CO}_{2}\right)$ emissions from the industrial sectors worldwide (IEA, 2011). World paper and paperboard demand and production are increasing; annual paper and paperboard production is expected to grow from approximately 365 million tonnes (Mt) in 2006 to between $700 \mathrm{Mt}$ (low estimate) and $900 \mathrm{Mt}$ (high estimate) in 2050 (IEA,

\footnotetext{
* Corresponding author. Tianjin Key Laboratory of Pulp and Paper, Tianjin University of Science and Technology, No. 29, 13th Ave., TEDA, Tianjin 300457, China. Tel.: +86 1332333 9936; fax: +86 2260600300.

E-mail address: Lingbo.Kung@gmail.com (L. Kong), AHasanbeigi@lbl.gov (A. Hasanbeigi), LKPrice@ lbl.gov (L. Price).
} 
2009). The largest share of this growth will take place in China, India, and other developing Asia countries (Figure 1). This remarkable paper and paperboard production increase will consequently cause a corresponding significant increase in the pulp and paper industry's absolute energy consumption and $\mathrm{CO}_{2}$ emissions.

Figure 1. World paper and paperboard production (IEA, 2009)

The pulp and paper industry ranks fourth in terms of energy consumption among industries; however, it is one of the least $\mathrm{CO}_{2}$-intensive industries because the widely utilization of biomass within this sector. The pulp and paper even could be produced without $\mathrm{CO}_{2}$ emissions, theoretically, according to International Energy Agency (IEA) (IEA, 2007). In general, the $\mathrm{CO}_{2}$ emissions involved in the pulp and paper industry consist of direct and indirect emissions. Direct emissions are from combustion of fossil fuels onsite and also include non-energy-related emissions such as those from lime kilns, landfills, and wastewater treatment plants. Indirect emissions are associated with off-site generation of steam and electricity that are purchased by or transferred to the mill (NCASI, 2008). Among these emission sources, energy-related emissions are by far the most significant (Kramer et al., 2009).

Studies have documented the potential to reduce energy and $\mathrm{CO}_{2}$ emissions by implementing commercially available energy-efficiency technologies in the pulp and paper industry (Worrell et al., 2001; Kinstrey and White, 2006; IEA, 2007, 2010a, 2011; UNIDO, 2010; Zafeiris, 2010; Hong et al., 2011; Kong et al., 2015). IEA (2010a) reported total energy savings for the global pulp and paper industry was $35 \mathrm{Mt}$ of oil equivalent (Mtoe) in 2007 , equivalent to $21 \%$ of this sector's total energy use in the same year. Worrell et al. (2001) found total technical potential for primary energy savings equal to $31 \%$ of 1994 energy use in the U.S. pulp and paper industry. Zafeiris (2010) analyzed the technical potentials of energy and $\mathrm{CO}_{2}$ emissions reduction for dominant pulp and paper making countries up to 2030 and concluded that the greatest $\mathrm{CO}_{2}$ mitigation potential was located in China, followed by the U.S. and Canada. Hong et al. (2011) identified total energy savings potential was $6.5 \%$ of 2009 energy use in the Taiwanese pulp and paper industry. Kong et al. (2015) evaluated the energy saving and $\mathrm{CO}_{2}$ emissions reduction potential in China's pulp and paper industry using energy conservation supply curve method. The results show that the cost-effective and technical energy conservation potentials represent $17 \%$ and $23 \%$ of primary energy in 2010 , respectively. Since $1990, \mathrm{CO}_{2}$ emissions intensity of the European paper industry has decreased by approximately 25 percent, the Australian pulp and paper industry about 20\%, and the Canadian pulp and paper industry over 40\% (Worrell, 2011). However, given the projected continuing increase in pulp and paper production, future reductions (e.g., by 2030 or 2050) in energy use and $\mathrm{CO}_{2}$ emissions will require additional innovations beyond the technologies available for implementation today. Innovations will likely include development of different processes and materials for pulp and paper production or technologies that can economically capture and store the $\mathrm{CO}_{2}$ emissions. The development of these emerging technologies and their deployment will be a key element in the pulp and paper industry's midand long-term climate change mitigation strategies.

Many studies from around the world have identified energy-efficiency technologies for the pulp and paper industry that have already been commercialized (Alsema, 2001; Bajpai, 2010; EC, 2001; U.S. EPA, 2010; FOE, 2005; ITP, 2006c, 2011b; Jaccard/Willis, 1996; Kramer et al., 2009, 2010; NEDO, 2008; Zafeiris, 2010). A detailed summary of commercial available energyefficiency measures and technologies applicable to pulping and papermaking can be found from 
the ENERGY STAR Guide (Kramer et al., 2009, 2010), in which the available technologies have been discussed that can be implemented at the component, process, facility, and organization levels. There are also some literatures focused on the aspect of environmental impact, ecoefficiency, and cleaner production of the pulp and paper sector (Abbasi and Abbassi, 2004; AbouElela et al., 2008; Avşar and Demirer, 2008; Cui et al., 2011; Dias and Arroja, 2012; Gabbrielli et al., 2006; Leon et al., 2014; Ren, 1998; Siitonen and Ahtila, 2010; Silvo et al., 2009; Thollander and Ottosson, 2010; Wang et al., 2013; Wang et al., 2011). However, information is limited or not easily accessible regarding emerging or advanced energy-efficiency technologies for the pulp and paper industry that have not yet been commercialized. This paper consolidates these recent developed new technologies aimed at providing a well-structured resource of information on this topic for engineers, researchers, investors, policy makers, pulp and/or paper companies, and other interested parties.

\section{Methodology}

The information presented for each technology was collected from various publically available sources. Latest literatures in terms of reports, books, thesis, journal papers, patents, conference proceedings, technical bulletins, web materials, reference documents on best available/practice techniques, handbooks on industrial energy efficiency, policies and climate mitigation strategies have been complied. Although it covers the main emerging energy-efficiency technologies for the pulp and paper industry, the list of emerging technologies addressed is not exhaustive.

The overview of the emerging energy-efficiency technologies covered in this paper is presented using a standard structure for each technology. First, we briefly describe the technology, including background, theory, pros and cons, barriers and challenges, and case studies if available. Next, we present the energy, environmental, and other benefits of the technology as well as cost information if available. We also include a block diagram or picture for some technologies. Finally, we identify the commercialization status of each technology along with resources for further information.

Emerging in this paper indicates technologies that are both pre-commercial but near commercialization and technologies that have already entered the market but have little current market share. The commercialization status for each technology is as of the writing of this paper and uses the following categorization:

- Research stage: the technology has been studied, but no prototype has been developed

- Development stage: the technology is being studied in the laboratory, and a prototype has been developed

- Pilot stage: the technology is being tested at an industrial-scale pilot plant

- Demonstration stage: the technology is being demonstrated and tested at the industrial scale in more than one plant but has not yet been commercially proven

- Semi-commercial stage: the technology is proven and is being commercialized but has a very small market share

The categorization used in this paper to rate the maturity of a technology is different from that of technology readiness level (TRL). TRL is based on a scale from 1 to 9 with 9 being the most mature technology. For this work, we thought having 9 level of technology maturity level is a bit too many and may confuse our audience. Also, different definitions are used for different TRL 
level by various organizations and institutions. Therefore, we develop the fewer technology maturity level which is consistent across our different similar studies on emerging technologies for various industries (Hasanbeigi et al., 2012, 2014). It should noted that overall our technology maturity levels are in line with TRL levels with some TRL levels being combined in our level.

The subsections below describe recent developments of technologies to improve energy efficiency in the different steps of the pulping and papermaking process, as well as emerging byproduct, biomass, and waste heat utilization technologies for the pulp and paper industry. Table 1 shows the emerging technologies presented in this paper and makes a comparison for some of their characteristics.

Table 1. Emerging technologies for the pulp and paper industry and a comparison of their benefits and commercialization status

\section{Emerging Energy-efficiency Technologies}

\subsection{Emerging Raw Material Pre-treatment Technologies}

The pre-treatment technology of raw material (wood chips) is applied prior to the pulping process in order to improve the pulping efficiency. Table 2 shows the energy savings, environmental and other benefits as well as commercialization status of microwave, chemical (oxalic acid), and biological pre-treatment technologies. The description of each technology is presented below.

\section{Table 2. An overview of emerging raw material pre-treatment technologies}

\subsubsection{Microwave Pre-treatment}

In traditional chemical pulping, most of the energy and chemicals used for driving the chemical reactions in wood chips to cleave covalent bonds between fibers. Microwave pre-treatment technology alters the cellular microstructures that control permeability in wood so that the pulping chemicals can pass more easily to the center of the chips, which reduces both the amount of energy and chemicals needed for the pulping process (U.S. DOE, 2005).

Microwave pre-treatment reduces the amount of energy required for chemical pulping due to lower H-Factor. It can also decreases lime kiln fuel consumption because fewer chemicals are used in pulping process. It is reported that microwave pre-treatment could decrease chemical usage and $\mathrm{H}$ Factor by around 40 percent while still producing pulp with acceptable quality (Compere, 2006). The technology also allows pulping chemicals to pass easily into larger and more diverse-sized wood chips (ITP, 2011b). In addition, hemicellulose recovered from black liquor can be reused in the pulping process, which could dramatically increase the pulp mill's yield (ITP, 2010). However, microwave pre-treatment will increase the electricity use significantly. Also, it may results in potential damage to pulp fibers and loss of paper strength.

Microwave pre-treatment could be retrofitted into existing chemical pulp mills to increase pulp yield and energy efficiency and minimize chemical usage (ITP, 2007a). Assuming 55 million tonnes per year of chemical pulp in the U.S. pulp and paper industry, annual energy savings could be as much as 116,050 terajoules (TJ) (Compere, 2006). 


\subsubsection{Chemical Pre-treatment with Oxalic Acid}

Chemical pre-treatment mainly uses oxalic acid (OA), acid leaching, and electrochemically treated salt solutions to enhance the refining efficiency in mechanical pulping (ECOTARGET, 2009). Chemical pre-treatment can significantly reduce energy use while does not adversely affect the final paper product; under optimized conditions, it even can improves paper strength and brightness ( $\mathrm{Li}$ et al., 2011).

The OA pre-treatment is incorporated in a mechanical pulping in a manner similar to traditional chemical pre-treatments (see Figure 2) (Swaney et al., 2003b). BioPulping International Inc. developed the OA pre-treatment technology jointly with several industrial and university partners (ITP, 2010). Brief pre-treatment of different types of wood chips using 0.05 to 6 percent of a dilute the OA solution can reduce the electricity used in mechanical pulping by 20 to 30 percent compared to the amount used in conventional pulping without pre-treatment (Akhtar et al., 2007). In addition, the OA pre-treatment improves paper strength and reduces resin content by approximately 30 percent prior to pulping (ITP, 2011b).

Figure 2. OA pre-treatment in TMP mill (Swaney et al., 2003b)

A pilot-scale trial of the OA pre-treatment at the Andritz pilot plant in Springfield OH (U.S.) reduced mechanical pulping energy use by approximately 25 percent. The expected payback period is 2 years or shorter, which makes this technology financially attractive (ITP, 2010). The OA pretreatment technology also removes hemicellulose, which could be converted into high-value chemicals, such as cellulosic ethanol. However, the OA pre-treatment increases consumption of bleaching chemicals. However, OA pre-treatment increases consumption of bleaching chemicals. In addition, it will result in pulp yield and brightness loss. O\&M costs of mechanical pulping also increase because of the added the OA pre-treatment unit.

\subsubsection{Biological Pre-treatment}

Biological pre-treatment is developed to decrease the energy consumption for mechanical pulping through modifying the cell wall of fibers and changing its external environment to enhance refining without jeopardizing pulp quality (Viforr, 2008). Although biotechnology has successfully been used in other phases of the pulp and paper production process, it has been challenging in chips pre-treatment because of size incompatibility between the molecules of enzymes and the dimensions of pores (Bajpai, 2012).

The two common biological pre-treatment technologies used on wood chips in mechanical pulping are fungal and enzymatic. Fungal pre-treatment was implemented on a conventional mechanical pulping line in Wisconsin (U.S.) that produced 220 tonnes per day (tpd), reducing energy costs by 33 percent from 121\$/tonne to 81\$/tonne (Swaney et al., 2003a). Biological pre-treatment also improve fiber strength and reduces pitch content. However, it will increases bleaching chemical consumption. Because biological pre-treatment is an additional operation, operations and maintenance $(\mathrm{O} \& \mathrm{M})$ costs also increase. But the overall costs of mechanical pulping with biological pre-treatment are lower because of the large amount of energy saved with biological pretreatment. A case study conducted by Swaney et al. (2003) shows the net cost savings are about 18 $\mathrm{US} \$ / \mathrm{t}$ of furnish pulp at the mill in Wisconsin. Economic analyses indicate that fungal pretreatment is both technologically feasible and economically beneficial (Kramer et al., 2009). The 
fungal pre-treatment prior to mechanical pulping has also been scaled up and demonstrated at a TMP mill in Brazil (Swaney, 2002).

Enzymatic pre-treatment uses one or more enzymes such as cellulase, hemi-cellulase, xylanase, pectinase, or laccase (Wang et al., 2007). The cellulase, xylanase, and pectinase pre-treatments have been tested jointly by several partners (including KCL, STFI-Packforsk, CTP, VTT, Holmen Paper, Stora Enso, UPM-Kymmene and Metso) that use different types of equipment. Use of xylanase resulted in the greatest energy savings: a 25-percent decrease. Cellulase pretreatment resulted in a 20-percent energy reduction, and pectinase pre-treatment reduced energy usage by 10 percent compared to refining without enzymatic pre-treatment (Viforr, 2008). The main drawback of all enzymatic treatments is that they decrease fiber length. More work is needed to optimize the process and demonstrate its maximum potential before commercialization.

\subsection{Emerging Pulping Technologies}

The subsections below describe the following emerging energy-efficiency technologies in pulping process: directed green liquor utilization (D-GLU), membrane concentration of black liquor, dual-pressure reheat recovery boiler, borate auto-causticizing, steam cycle washing, recycled paper fractionation. Table 3 presents an overview of these emerging pulping technologies.

Table 3. An overview of emerging pulping technologies

\subsubsection{Directed Green Liquor Utilization Pulping}

Green liquor is naturally rich in hydrosulfide ions, which can accelerate pulping and provide a high-value product (ITP, 2011b). However, in generally, green liquor is used to react with lime $(\mathrm{CaO})$ in a process called causticizing to produce calcium carbonate $\left(\mathrm{CaCO}_{3}\right)$ and regenerate white liquor (a mixture of $\mathrm{NaOH}$ and $\mathrm{Na}_{2} \mathrm{~S}$ ) for chemical pulping (Naqvi et al., 2010). Directed green liquor utilization (D-GLU) pulping is based on the reuse of green liquor for pre-treatment of wood chips prior to kraft pulping. Different from the conventional kraft pulping process in which all the green liquor is used to regenerate white liquor, this new pulping technology redirects 20 to 30 percent of the green liquor from the causticizing process to pulp pre-treatment before cooking in the digester. As a result, not only the lime kiln load but also the energy consumption of the digester can be reduced (Lucia, 2006).

North Carolina State University and the Georgia Institute of Technology (Georgia Tech) performed laboratory-scale pulping and fiber analyses for some kraft mills (e.g., Evergreen Pulp mill, Temple-Inland mill, and Evadale pulp mill) as support for mill trials of the D-GLU pulping process (ITP, 2006c). D-GLU pulping has also been demonstrated in Finland and reportedly increase pulp yields, produce higher fiber strength, reduce digester alkali demand, reduce lime kiln load by up to 30 percent, increase the bleachability of pulp, and reduce energy use by up to 25 percent (ITP, 2011a). Compared to conventional kraft pulping, D-GLU pulping saves almost 50 percent alkali, and more than doubles pulp viscosity at the similar Kappa number with higher pulp yield (Lucia, 2005). 
Implementation of D-GLU pulping is straightforward and requires minimal capital investment. Energy savings are the main driver for implementation of this technology. Among the potential negative impacts are that green liquor pulping might reduce the heat value of black liquor and increase black liquor dead load (Lucia, 2006). Environmental and scaling issues related to nitrogen emissions during recovery (because of the inclusion of organic additive), higher sulfide off-gassing during pulping, and build-up of scale in the digester and/or evaporators are other issues associated with this technology that need further investigation.

\subsubsection{Membrane Concentration of Black Liquor}

Membrane technology concentrates high molecular weight solids from low molecular weight fraction of weak black liquor, as Figure 3 shows. The most utilized membrane technologies in the pulp and paper industry are microfiltration (MF), ultrafiltration (UF), nanofiltration (NF), and reverse osmosis (RO) (Dillard, 1998). These technologies use pressure gradient to separate the liquid stream through a porous or semi-permeable membrane as two liquid stream (Dillard, 1998). After membrane process, the concentrated black liquor could achieve higher solids content. Membrane technology has a broad range of separation capability at molecular level.

UF membranes have been operating since 1980s to separate color, BOD, COD, and AOX from caustic effluents (Dillard, 1998). The background, research, development and applications of membrane technologies including MF, NF, UF, and RO in different areas of the pulp and paper industry are surveyed by Adnan and coworkers (Adnan et al., 2010). Many studies have been conducted to investigate UF membrane technology for treating black liquor to recovery the valuable organics (Bhattacharjee et al., 2006; Dafinov et al., 2005; Holmqvist et al., 2005; Jönsson and Wallberg, 2009; Wallberg et al., 2005). Most of these applications are still in the laboratory stage. The solids content of weak black liquor could be concentrated to over 30 percent using UF membrane technology (Wallberg et al., 2005).

One of the drawbacks in the utilizing of membrane technology for black liquor pre-evaporation is the marked decline of permeate flux and associated fouling problems (Bhattacharjee and Bhattacharya, 2006). The capital and operating costs are high, but improvements are being made in membranes and process equipments. The U.S. DOE Innovative Manufacturing Initiative announced in June 2012 for development of highly durable membrane coating for black liquor concentration process with US\$2.6 million award, led by Teledyne Scientific \& Imaging, LLC (TS\&I) in partnership with the Agenda 2020 Technology Alliance (Teledyne, 2012). By replacing the first two stages in conventional multiple-effect evaporators, this new technology has the ability to save the U.S. pulp and paper industry energy about 116 PJ per year (Teledyne, 2012).

Figure 3. Membrane technology for black liquor pre-evaporation (Sholl, 2011)

\subsubsection{Dual-pressure Reheat Recovery Boiler}

Dual pressure recovery boiler is designed as a combination of a classic recovery boiler and a classic subcritical utility boiler (Hicks et al., 2009). It allows pulp mills to take advantage of the power generation potential of the high pressure reheat cycle on a recovery boiler (Monacelli et al., 2008). The dual pressure recovery boiler consists of a lower furnace and an upper furnace, shown in Figure 4. The lower furnace is operated at a lower temperature to prevent or reduce corrosion of the lower furnace tubes caused by the reducing environment. The lower furnace can be either a low 
pressure natural circulation steam generating system or economizer. While the upper furnace is not exposed to a reducing environment, so it is not as susceptible to severe corrosion rates. The upper furnace is operate at higher temperatures and pressures which permit implementation of higher efficiency reheat steam cycles (Graves et al., 2007). This design eliminates the need for the exotic metals that are required to withstand a corrosive operating environment in the lower furnace (B\&W, 2009).

Figure 4. Diagram of dual pressure reheat recovery boiler (Hicks et al., 2009)

The dual pressure recovery boiler can be coupled to a variety of condensing, non-condensing or a combination of condensing and non-condensing turbine cycles to provide a large increase in power generation efficiency (Monacelli et al., 2008). The new reheat recovery technology will generate more electrical power from the pulp mill steam cycle. Efficiency improvements that result from incorporating a gas-over-tube tubular air heater into the recovery boiler design will increase boiler efficiency and allow for greater application of feedwater heating which will improve the steam cycle efficiency (Hicks et al., 2009).

Although this is a new configuration of equipment in recovery boiler, the technologies are mature, proven and very familiar to the boiler industry. It could increase the power generated from recovery boiler by 30 to 130 percent for pulp mills that have low solids and direct contact evaporators (B\&W, 2009). This additional generated power can transform some mills into net power generators with little or no increase in heat input and reduce the mill's $\mathrm{CO}_{2}$ emissions at the same time (B\&W, 2009; Hicks, 2011).

\subsubsection{Borate Auto-causticizing}

Caustic is typically recovered from the spent pulping chemical in two stages: first, $\mathrm{Na}_{2} \mathrm{CO}_{3}$ is formed by the combustion of black liquor in the recovery boiler, and then caustic is formed by the addition of $\mathrm{CaO}$ to $\mathrm{Na}_{2} \mathrm{CO}_{3}$ in the re-causticizing plant. Lime is then recovered in the lime cycle through the calcination of lime mud. Auto-causticizing could be an attractive alternative for kraft mills because it allows higher caustic production without increasing lime demand and can even eliminate lime demand (Kochesfahani and Bair, 2002).

Borate auto-causticizing uses sodium borate $\left(\mathrm{Na}_{2} \mathrm{~B}_{4} \mathrm{O}_{7} \cdot 5 \mathrm{H}_{2} \mathrm{O}\right)$ to replace lime. Each tonne of Neobor added to the pulping process replaces 10 to 30 times its weight in lime (RTM, 2010). The principal auto-causticizing reaction that occurs in the recovery boiler is between sodium metaborate $\left(\mathrm{NaBO}_{2}\right)$ and $\mathrm{Na}_{2} \mathrm{CO}_{3}$ in the molten smelt, which forms tri-sodium borate $\left(\mathrm{Na}_{3} \mathrm{BO}_{3}\right)$. The $\mathrm{Na}_{3} \mathrm{BO}_{3}$ reacts with the water in the smelt dissolving tank to form sodium hydroxide $(\mathrm{NaOH})$ and regenerate $\mathrm{NaBO}_{2}$ (see Figure 5) (Bjork et al., 2005). The borate compounds remain in the liquor cycle, self-regenerating to be used again in producing caustic. $\mathrm{NaBO}_{2}$ drives autocausticizing reactions in the recovery boiler and forms $\mathrm{NaOH}$ in the smelt dissolving tank without the use of lime kilns or additional recovery processes, thus reduces energy consumption and increases causticizing and calcining capacities. For kraft and soda pulp mills, reducing the lime kiln load not only translates to lower operating costs, energy consumption, and emissions, but also significantly reduces the amount of lime mud disposal costs (ITP, 2011b).

Figure 5. Borate auto-causticizing process (ITP, 2011b) 
A trial of partial auto-causticizing with sodium borate was first conducted at Georgia-Pacific Camas mill WA (U.S.) from 1999 to 2000 for a period of more than 16 months (Hunter et al., 2001). In Europe, a full-scale partial borate auto-causticizing trial has been under way since November 2002 at the Stora Enso Norrsundet mill in Sweden (Bjork et al., 2005). In this trial, the total lime requirement has been reduced by about 7 percent, and the auto-causticizing level has typically been 9 to 11 percent during the 15 -month period. There is some indication that borates may enhance pulp yield as well (Bjork et al., 2005). Partial auto-causticizing in the P.H. Gladfelter Co. mill in Spring Grove PA (U.S.) increased production by roughly 5 percent in 2007 (ITP, 2011b). However, the full borate auto-causticizing, which uses borates to drive all the causticizing reactions instead of just lime causticizing, is still undergoing further research and testing (ITP, 2006c).

\subsubsection{Steam Cycle Washing}

Efficient washing is critical to maximize return of pulping liquor to chemical recovery and to minimize the cost of steam evaporation as well as to minimize washing loss into the bleach plant because excess pulping liquor will increase consumption of bleaching chemicals (Bajpai, 2010). Various washing technologies have been developed during the past 50 years, including drum washing, diffusion washing, press washing, displacement washing, belt washing, and dilution/extraction washing (Bajpai, 2010). Rotary drum washing is the most common washing technology used in pulp mills today with a dilution factor ${ }^{1}$ of 3 to 4 tonnes water per tonne of oven-dry pulp (Muehlethaler et al., 2008).

The steam cycle washer is designed to dewater and wash wood pulp using counter current washing, steam, and high-differential pressure. The entire process takes place within a pressure vessel at 8 bar operating pressure. The washing consistency ${ }^{2}$ of the developed steam-cycle washer is 28 to 32 percent (fiber concentration about 280 to $320 \mathrm{~kg} / \mathrm{m}^{3}$ ), and the dilution factor is only 0 to 0.5 tonnes of water per tonne of oven-dry pulp. The amount of wash water required is between 2.5 and 3 tonnes/tonne oven-dry pulp, compared to 12 to 13 tonnes/tonne oven-dry pulp with the most common rotary drum washing technology, i.e., a reduction of 70 to 75 percent (Muehlethaler et al., 2008). This technology uses less water compared to conventional washers because it allows the pulp mat to be washed at a high consistency (ITP, 2006e). As a result, less energy is required for pumping and heating in the thickening, screening, and evaporation operations.

A pilot demonstration conducted at the Port Townsend Paper Mill (WA, U.S.) achieved a 20percent decrease in electricity consumption and a 40-percent overall reduction in fuel or steam consumption for unbleached pulp production (Muehlethaler et al., 2008). Steam cycle washing is undergoing demonstration and commercialization. The Idaho National Laboratory is collaborating with Steam Filter LLC in the design, fabrication, and installation of a 450 to 500 Adt per day steam cycle washing machine for unbleached pulp. The feasibility of this process has been tested and demonstrated through bench-scale and pilot tests (U.S. DOE, 2008).

\footnotetext{
${ }^{1}$ The dilution factor is the actual quantity of water used in pulp washing compared with the theoretical amount required to displace the liquor from the thickened pulp.

${ }^{2}$ The washing consistency means the fiber concentration in the pulp slurry during washing process, to some extent, it reflects how much water be used indirectly. A lower washing consistency represents higher water consumption.
} 


\subsubsection{Recycled Paper Fractionation}

Recycled paper fractionation is not a new concept, but only a small number of recycled paper mills use this technology in deinking process. The purpose of fractionation is to improve the quality of deinked pulp (DIP) by separating long fibers from short fibers and fines, according to defined criteria such as size or deformability. Figure 6 presents the comparison of a traditional standard two-loops deinking and a single-loop deinking with recycled paper fractionation.

Figure 6. Single-loop fractional deinking (ECOTARGET, 2009)

(Standard 2-loops [left]; new single-loop deinking with recycled paper fractionation [right])

Fractionation can be done both in pressure-screens and in centrifugal cleaners. Fractionation during recycled paper pulping can removes the detached ink particles from the vicinity of fibers and thus prevents their excessive redeposition into the fibers. The ink particles need to be removed once they are released to minimize the concentration of ink that remains after pulping. This may require that the detached ink particles be removed from the pulp before defibration is completed. Removing detached ink particles with multiple repeated pulping and fractionation stages reduces the amount of attached ink to significantly lower levels than are possible with a conventional pulping arrangement (Kemppainen et al., 2010).

The energy requirement for recycled paper fractionation is lower than conventional multi-stage flotation deinking system. However, when fractionation is used, additional bleaching chemicals might be required to compensate for the reduced flotation capacity. Andritz in Austria has tested the potential of using recycled paper fractionation in a deinking line. The fractionation deinking line has a 13- to 22-percent lower capital cost compared to traditional DIP lines. Using fractionation can reduce electricity use by 11 to 13 percent and thermal energy use by 40 percent (Hertl, 2008). The technology is also being implemented and tested at Pearl Paper Mill in Switzerland (Kramer et al., 2009).

\subsubsection{Surfactant Spray Deinking}

Surfactant spray is a new technology for recycling various grades of paper that improves ink removal, reduces the use of chemicals and the loss of fiber and water during deinking, and provides better process control than current deinking technologies (Zhao et al., 2004). The surfactant increases ink removal by adsorbing onto the surfaces of the ink particles and reducing their hydrophobic characteristics, so they can more readily be separated and removed from the pulp suspension. Use of surfactants also improves process control by preventing dilution of the foaming agent in the bulk volume of the pulp mixture. Because surfactant spray significantly improves the deinking process, reduces the use of chemicals and the loss of fiber and water, it reduces operating costs.

Surfactant spray deinking uses an atomizer to spray foam at the top of the flotation cell. The foaming agent generates stable foam for ink removal, a collector is applied to agglomerate small ink particles for removal, and a dispersant is used to prevent ink particles from re-depositing onto fiber surfaces (Zhao et al., 2004). The concentration and distribution of various surfactants is controlled during the surfactant spray deinking process (Deng and Zhu, 2004).

Surfactant spray technology has been demonstrated in both laboratory- and pilot-scale flotation deinking trials at IPST in the U.S. and in Voith-Sulzer's commercial flotation cells for deinking 
old newsprint, old magazines, and old corrugated container board (Delozier et al., 2005; Deng and Zhu, 2004). It was successfully implemented in a single flotation unit within the deinking line of a mill producing newsprint from 100-percent secondary fiber, with a more than 50-percent reduction in fiber loss from the unit without negatively affecting final pulp quality (Delozier et al., 2005). Single-cell commercial runs (450 tpd DIP) using surfactant spray in a flotation deinking line showed a 3.5-percent increase in yield, 380 liters per minute savings in water use, and 10percent chemical savings (Deng and Zhu, 2004). Surfactant spray technology can be easily retrofitted into an existing system without significant modifications and capital cost. The estimated capital investment is approximately $\$ 10,000$ for one flotation cell (Deng and Zhu, 2004).

\subsection{Emerging Papermaking Technologies}

Table 4 shows the energy savings, environmental and other benefits as well as commercialization status of the emerging technologies in papermaking process, including Aq-vane technology, high consistency papermaking, dry sheet forming, displacement pressing, and new fibrous fillers. The description of each energy-efficiency technology is described below.

Table 4. An overview of emerging papermaking technologies

\subsubsection{Aq-vane Technology}

Stratified forming is used to produce multi-layer paper and paperboard. Instead of being made from a single paper web that forms a sheet containing mixed or uniform materials throughout, conventional linerboard consists of several distinct layers composed of different raw materials that are formed with different headboxes. Stratified forming technology was developed to produce multi-layer paper and paperboard using only a single headbox, which reduces complexity as well as energy and raw materials consumption (Soderberg, 2006).

However, in a stratified forming set-up, as Figure 7 shows, the pulp streams are separated by vanes or lamellas which form a wake in which uncontrolled mixing can take place, which degrades the purity of the layers formed using this technology (Soderberg, 2006, 2009). A new type of stratified technology, Aq-vane, was developed by STFI-Packforsk to overcome this problem (Soderberg, 2006). This technology entails injecting a thin passive liquid layer (a liquid vane or Aq-vane) in the headbox through a narrow hollow channel between neighboring pulp streams, which prevents mixing between the layers (Soderberg, 2008).

Figure 7. Comparison of conventional and new stratified forming technology (Soderberg, 2006)

Trials of Aq-vane technology on three types of paper produced by the EuroFEX pilot paper machine showed that, with this technology, the filler content in papermaking can be increased to 45 percent from the previous 35, and energy consumption was reduced by 16 percent (ECOTARGET, 2009). Another feature of the Aq-vane technology is that the layer purity and separation can be controlled externally by tuning a set of process parameters. This creates the possibility of widespread industrial application of stratified forming, improved product quality, 

applied to paper grades of almost any grammage (Soderberg, 2009).

\subsubsection{High Consistency Papermaking}

High consistency papermaking require that the approach and short circulation systems, fluidization and dewatering processes operated under the condition of high consistency (EC, 2012). The processed pulp enters at the forming section, and has more than double the consistency (3 percent) compared to that of normal slurry. High consistency could increase forming speed and leads to energy savings in the pressing section as a result of lowing dewatering and vacuum power requirements (Martin et al., 2000b). Increasing the forming consistency from 0.7 to 7 percent would reduce the flows around the wet end by 10 fold. Since 25 percent of energy consumption is used for pumping water and stock, remarkable energy savings could be realized (Cichoracki et al., 2001).

Efforts aimed at increasing the forming consistency have been going on since 1980s, but with little success (EC, 2012). This development has been limited to a consistency of around 3 percent due to the deterioration in sheet properties. Recently, it has been suggested that up to 6 percent may be possible while still achieving good formation (Cichoracki et al., 2001). A high consistency device was built by Cichoracki et al. (2001) for forming webs at the consistency of 5-15 percent. To date, webs have been formed at 5-12 percent consistency, with grammages ranging from 275 to 1000 $\mathrm{g} / \mathrm{m}^{2}$. The web width is $300 \mathrm{~mm}$ and speeds up to $700 \mathrm{~m} / \mathrm{min}$ are currently possible. However, a current drawback, which still needs to be overcome, is the defiberability of the sheet as compared to that of conventional market pulp sheets. Also, the modern paper machines have winder web width and higher machine speed than can be achieved with the current technology mentioned above.

Due to improved fibers retention, chemical use and the environmental impact of the process will also be reduced. Results from early high consistency research indicate that in addition to economic and environmental benefits other advantages may be gained in terms of sheet properties and process variables. Stock storage and pump size could be reduced, and initial dewatering elements in the forming section could be eliminated, all resulting in simplified wet-end section of papermaking and a shorter less expensive paper machine (Cichoracki et al., 2001; EC, 2012). It was reported that 1015 percent savings in capital costs can be realized for paper machine wet-end since it allows for reductions of the size of both the forming and drainage area (Martin et al., 2000b). Progress still needed for high consistency papermaking in the mixing of fibers and chemicals and in screening, air removal, fluidization, dewatering of furnish, and in process control (EC, 2012).

\subsubsection{Dry Sheet Forming}

The principle behind dry sheet forming is the production of paper without adding water (de Beer et al., 1998). It relies on high levels of turbulence in the air stream to produce paper products. Fibers can be dispersed either mechanically or using "air laying" techniques. In air laying, the fibers are suspended in the air, and the paper is formed in this suspension. Resins are sprayed on the sheet and are then polymerized to help form the web (de Beer et al., 1998). The air laying technology permits a higher production rate and better control of air streams compared to other dry sheet forming processes. A typical dry sheet forming line consists of four units: fiber preparation, web formation, web consolidation, and finishing (Jiang, 1997).

Air-laid dry sheet forming technology was first commercialized during the early 1980s by Moeller and Jochumsen, a Danish firm. The worldwide installed capacity of this technology is about 350,000 t/year and growing rapidly (Xu et al., 2010). New capacity additions of 120,000 

estimated that 50 percent of drying energ $\mathrm{kWh} / \mathrm{t}$ paper of additional electricity consumption to maintain the air stream and motor drive for the equipment using air-laid dry sheet forming technology (Martin et al., 2000b; Xu et al., 2010). Because no water is used in this technology, it also avoids the wastewater effluent and treatment that are part of conventional paper mill operations.

The disadvantages of dry sheet technology include increase electricity use in paper forming, less uniform paper thickness, lower sheet strength, and reduced smoothness. However, the paper produced with dry sheet technology tends to be softer than that produced by conventional technology. As a result, dry sheet forming technology is often used to produce personal care products (diapers, feminine hygiene, and adult incontinence products, etc.) and some specialty products (tableware, medical products, and hot towels, etc.) (Martin et al., 2000b). Another barrier is its lower speed for producing the standard paper grades compared to the conventional technology.

If this technology were commercialized to manufacture standard paper grades, direct investment costs could be 30 to 50 percent of those for a conventional non-integrated paper mill. In addition, O\&M costs are expected to be lower (de Beer et al., 1998; Jiang, 1997). The technology has not yet been used for producing other types of paper products although it has been demonstrated that producing corrugated medium and molding board is possible. It appears that dry sheet forming technology will continue to be developed for specialty applications and is not likely to be adapted in the near future for production of standard paper grades.

\subsubsection{Displacement Pressing}

The current pressing technology uses mechanical pressure to remove water from the wet web. Although this method is effective, it produces a maximum solids content of 50 to 55 percent. Solids content of 65 percent has been reported in laboratory studies, and the current theoretical limit of paper press is 80 percent solids (Agenda2020, 2010).

Displacement pressing technology is a new method for pressing the paper web that has been developed at the laboratory scale to enhance the solids content of the web out of the press section. This technology combines mechanical and air pressure, pressing web lightly while forcing air through it and using special pressing fabrics with a special four-roll Beck cluster press (BCP). $\mathrm{BCP}$ provides a pressurized atmosphere that acts on the moving web and fabric. The special fabric designed for this process use this atmosphere to press the sheet and at the same time force air through the sheet to carry out displacement pressing. The effective dewatering as a result of its higher pressures and longer dwell times giving displacement pressing technology tremendous high speed potential (Beck, 2006).

A displacement pressing simulator was built by Voith Fabrics to develop and test pressing fabric on a small scale. Voith Fabrics also designed and built a narrow laboratory-scale BCP that is 5 inches wide. This study also looked at the effect of displacement pressing on sheet properties and found that this technology can produce a paper web with maximum paper solids content exceeding 60 percent (Beck, 2006). If this technology is successful, more than 30 percent of drying energy consumption could be reduced. Based on the obvious results of the small-scale BCP trial, Voith Fabrics built a one-meter pilot BCP press stand to determine scalability of the process. 


\subsubsection{Impulse Drying in Wet Pressing Process}

Impulse drying is a technology that improves the mechanical dewatering of paper and reduces the amount of water that needs to be removed in the subsequent dryer section (Xu et al., 2010). When impulse drying is used, the solids content of the paper web entering the dryer section can be as high as 65 percent (OIT, 1999) whereas the paper web can only reaches a solids content of about 40 percent in an ordinary press section. Even in the extended nip presses, the web can only reach a solid content of about 50 to 55 percent (Mujumdar, 2006). Some sources report the solids content of 55 to 65 percent can be realized with impulse drying (EC, 2001).

Impulse drying is a combination of pressing and drying. The paper web is exposed to an intense impulse of heat while under pressure between a press element and a heated element in a paper machine (see Figure 8) (Manninen et al., 2002). This avoids a sudden increase in the surface temperature of the web to a higher temperature than is employed in conventional technology (EC, 2001). The vapor generated at the hot surface pushes water through the compressed capillaries in the web toward the felt and finally the generated vapor can flow freely through these channels. Impulse drying can increase the paper drying rate by 50 to 500 times of conventional drying technology (de Beer et al., 1998). In addition, it improves paper productivity and quality, for example by increasing the smoothness and strength of the web. Trials on a linerboard production line demonstrated a 20-percent productivity improvement (Orloff et al., 2000).

Impulse drying technology was first developed in 1980 by IPST with the collaboration of Beloit Corporation (now part of Metso) (Orloff and Crouse, 1999). It can be retrofitted into an existing machine or incorporated into new machine. For new machines, the size and cost of a new paper machine with impulse drying can be less than that of a conventional machine (Xu et al., 2010). Installation costs range from $\$ 70$ to $\$ 100 / t$ paper although these cost data are not based on actual full-scale operating facilities (Martin et al., 2000b). A case-study by Natural Resources Canada showed that the capital investment for impulse dryers is \$97/t paper, and the O\&M costs are estimated be $\$ 10 / t$ paper less than for a conventional machine because with impulse drying the dryer section is shorter. The payback period is 7.2 years (Xu et al., 2010).

Figure 8. Impulse drying unit in press section (Manninen et al., 2002)

\subsubsection{New Fibrous Fillers}

Mineral fillers are commonly used to replace wood fibers in the production of paper products and to reduce production cost and energy consumption. The filler loading is limited to roughly 15 to 20 percent of a product because of paper strength and quality requirements (ITP, 2006b). If mineral filler exceeding those percentages was used in papermaking, it could degrade paper properties. However, G.R. International Inc. (GRI), in cooperation with several major industrial partners, has developed a new fibrous filler that may overcome these problems and achieve additional replacement of high cost wood fibers.

The fibrous fillers based on calcium and silica can displace more than $40 \%$ of the pulp for papermaking while maintaining paper properties and reducing energy consumption in some case studies (ITP, 2010). GRI and Lawrence Livermore National Laboratory (LLNL) demonstrated the chemical reaction that forms the new filler, and the filler manufacturing process and its paperenhancing capabilities were optimized in a scaled-up pilot reactor (ITP, 2006b). Energy savings 
from using new fibrous fillers are attributable to avoided wood pulp production and reduced drying energy due to an increase in the percentage of press solids in the sheet (Mathur, 2006). Reportedly, the use of this fibrous fillers could reduce energy consumption by 25 percent and costs by $\$ 10$ to $\$ 50 /$ t paper produced (ITP, 2006b).

The new advanced fibrous filler can also be used to replace other expensive fillers, such as $\mathrm{TiO}_{2}$ and silica. Fibrous fillers will also lead to better retention of fibers, additives, and pulp fines, resulting in significantly reduced COD and biological oxygen demand (BOD) in the mill process water. Fibrous fillers could be used in all paper and paperboard products. Free sheet papers are the most likely targets in the near term, but wood-containing papers and newsprint could eventually use this product as well (ITP, 2006b). GRI has a plan to expand the current prototype plant to a full commercial plant, and the technology is available for licensing (ITP, 2010).

\subsection{Emerging Paper Drying Technologies}

The energy savings, environmental and other benefits as well as commercialization status of the recent paper drying technologies are presented in Table 5. The description of each technology is presented below.

Table 5. An overview of emerging paper drying technologies

\subsubsection{Gas-fired Dryer}

The gas-fired dryer involves combusting natural gas and air in small dimples or cavities. The airflow creates a vortex within each dimple, resulting in highly stable mini flames and uniform drum surface temperatures (ITP, 2006d). This is a high-efficiency alternative to traditional steamheated dryers and is expected to exceed the performance of existing paper drying systems.

This new gas-fired dryer was initially evaluated in Gas Technology Institute (GTI) combustion laboratory and then successfully tested at Western Michigan University's pilot paper machine. The conventional steam heated dryer at Western Michigan University consumed about $21 \mathrm{~kW}$ of saturated steam heat to reach $120^{\circ} \mathrm{C}$ on the drum surface compared to less than $14.7 \mathrm{~kW}$ of heat is necessary for the gas-fired dryer to reach the same surface temperature. Moreover, about $260{ }^{\circ} \mathrm{C}$ of the dryer surface temperature was reached during linerboard production, which increased the drying rate by 4 to 5 times compared to the rate of existing steam-heated dryers (Chudnovsky et al., 2004). A full-scale demonstration is being conducted on a linerboard paper machine (ITP, 2006c).

This gas-fired dryer can be installed in new or existing equipment. This new gas-fired dryer is 75 to 80-percent energy efficient compared to 65-percent efficiency of steam-heated dryer, so its implementation would save much energy. In addition, it would help the paper industry increase production by 10 to 20 percent, resulting in remarkable capital costs savings for both retrofits and new capacity (Chudnovsky et al., 2004). Even if an existing paper machine is not drying-rate limited, the gas fired dryers will still reduce energy consumption. The payback period is estimated to be less than 1 year (Chudnovsky et al., 2004). 


\subsubsection{Boost Dryer}

The boost dryer technology combines condensate drying and press drying principles by using a dryer cylinder and a pressure hood. The web runs directly over the drying cylinder, which is heated with saturated steam at 6 to 12 bars above atmospheric pressure. On the outside of the web is a special engineered fabric and a steel belt. The belt, fabric and paper are pressed against the cylinder surface by water pressure. The water pressure is generated in a hood that encloses approximately three-quarters of the cylinder circumference and is set between 0.5 and 4 bars. The water temperature is between 60 and $90^{\circ} \mathrm{C}$ (Haase, 2005). The moisture in the web evaporates and condenses in the meshes of the cooled fabric. A small amount of the web moisture remains as steam between the fabric meshes. The fabric temperatures range between $70^{\circ} \mathrm{C}$ and $90^{\circ} \mathrm{C}$. The hot condensate evaporates after leaving the pressure hood. The evaporating condensate is exhausted as in a conventional dryer section, and its heat can be recovered using heat exchangers (Karner and Herzog, 2008).

Boost dryer technology could increase production where space is limited and improve paper strength. It can achieve higher drying rates than conventional drying because of the hood pressure, which presses the web against the cylinder surface and creates a better contact than in a conventional dryer. The heat-transmission coefficient of the web can also be significantly increased. Boost drying is primarily suitable for board and packaging paper production. It is reported that one boost dryer can replace several conventional dryers (Karner and Herzog, 2008).

The first prototype of the boost dryer was installed after the press section on the Voith pilot paper machine to evaluate boost drying during continuous process. The tests showed higher drying rates can be achieved with only 4.5 seconds of dwell time in the boost dryer compared 13 seconds in conventional drying. In addition, there was 40-percent improvement in the surface smoothness of the paper. Klingele paper mill in Weener (Germany) installed the first commercial-scale boost dryer technology in 2008 (Karner and Herzog, 2008).

\subsubsection{Condebelt Drying}

The Condebelt drying is a new paper drying technology that is based on the condensing belt principle. In the Condebelt drying process, the paper web is dried in a drying chamber between two steel belts instead of on traditional steam-heated cylinders (de Beer et al., 1998). One the up side of the web is the upper steel belt, and on the down side of the paper web are three layers: fine wire gauze, coarse wire gauze, and the lower steel belt (also shown in Figure 9). The upper steel belt is heated by steam at temperatures of $110^{\circ} \mathrm{C}$ to $160^{\circ} \mathrm{C}$, and the lower one is cooled by circulating water to approximately $80^{\circ} \mathrm{C}$ (Lee et al., 2000). The top side of the web is in direct contact with the upper steel belt, and the lower side of the web contacts a fine wire with a coarse wire underneath. The evaporated water passes through the wire gauze and condenses on the steel belt. The condensate is removed by pressure and suction. The pressure on the web can range from atmospheric to 10 bars.

Figure 9. Schematic of Condebelt drying process (Lee et al., 2000)

Laboratory tests of this technology showed very high drying rates, exceeding 145 kilograms per square meter per hour $\left(\mathrm{kg} / \mathrm{m}^{2} \cdot \mathrm{h}\right)$ at a metal temperature of $170^{\circ} \mathrm{C}$. The drying rate went as high as $500 \mathrm{~kg} / \mathrm{m}^{2} \mathrm{~h}$ for low-grade paper in pilot-scale tests (Mujumdar, 2006). Condebelt drying can 
also significantly improvement the resulting product's strength (by 20 to 60 percent), surface smoothness, dimensional stability, and resistance against humidity (EC, 2001). Currently, the Condebelt drying is best fit for paperboard drying. For other paper grades, drying under such unsymmetrical conditions will result in two-sidedness.

Two mills have installed this technology (Retulainen, 2001). The first installation is $2.5 \mathrm{~m}$ wide with a machine speed of $200 \mathrm{~m} / \mathrm{min}$ and has been running since 1996 at Stora Enso's Pankakoski board mill in Finland (Retulainen, 2001; Retulainen and Hamalainen, 2000). The second is $4.5 \mathrm{~m}$ wide with a machine speed of $650 \mathrm{~m} / \mathrm{min}$ and began operation in 1999 at Dong II Paper Mfg. in South Korea, producing linerboard and fluting (Lee et al., 2000; Retulainen, 2001). This technology can save an estimated 15 percent in steam consumption (or $1.6 \mathrm{GJ} /$ tonne paper) and can slightly reduce electricity consumption (i.e., $20 \mathrm{kWh} /$ tonne paper), with investment costs of $\$ 28 / \mathrm{t}$ paper for a retrofit and $\$ 110 / \mathrm{t}$ for new construction (Martin et al., 2000a). O\&M costs are not expected to be different from current practice (Xu et al., 2010). As a advanced technology, Condebelt drying is expected to be applied in other kinds of paper grades drying process.

\subsubsection{Microwave Drying}

Microwaves can perform a useful function in leveling out the moisture profiles across the wet paper web (Sander et al., 2003). When paper is heated using microwaves, high drying rates can be realized. Microwave paper drying has been investigated periodically since the 1960s. One of the first studies reported a 30-kW microwave dryer tested on a pilot paper machine (Ahrens, 2003). Previous studies indicated favorable economics and no damage to paper quality. Because the microwave energy absorption efficiency increases with greater water loads, microwave technology is especially suited for drying high basis weight paper grades. For lower basis weight paper, larger microwave applicators are needed to achieve high absorption efficiencies.

Microwave technology would be an add-on to the paper machine to improve the moisture profile of dried paper. It can be used in the press section to preheat the web and reduce the water load delivered to the dryer section. It can also be applied to the dryer section for pre-heating and to supplement existing cylinders that operate by conduction heating (ITP, 2006a). Microwave heating can be classified as a volumetric heat source. Therefore, microwave drying rates are not limited by the usual conductive or convective heat input resistances (Ahrens, 2003). If microwave drying technology is used in the press section, it will increase press dehydration, reduce dryer energy consumption, and enhance dryer efficiency and productivity. In addition, O\&M costs will be lower due to the reduction in numbers of cylinders relative to conventional dryer sections. However, microwave drying is not employed in paper machines yet as a result of higher electricity consumption to produce microwave and high initial capital investment.

IPST conducted a three-year project funded by the U.S. DOE. The project initially aimed at evaluating the feasibility of microwave paper drying technology and commercializing it. The feasibility study showed that microwave paper drying technology can increase paper machine speeds by 30 percent and reduce paper drying energy consumption by 20 percent with a payback period shorter than 2.5 years (Ahrens, 2003). 


\subsection{Emerging Byproduct/Biomass Utilization Technologies}

Table 6 shows the energy savings, environmental and other benefits as well as commercialization status of the emerging technologies of byproduct/biomass utilization technologies, including LignoBoost, biomass gasification, and integrated biorefinery. The description of each technology is presented below.

Table 6. An overview of emerging byproduct/biomass utilization technologies

\subsubsection{Black Liquor Gasification}

Black liquor gasification (BLG) is an emerging technology with a long research and development (R\&D) history. BLG entails pyrolyzing concentrated black liquor into an inorganic phase and a gas phase through reactions with oxygen or air at high temperatures (EC, 2001). BLG technology can be an alternative to using a recovery boiler to produce electricity, chemicals, or fuels such as dimethyl ether (DME), synthetic gas (syngas), methanol, hydrogen, or synthetic diesel (Naqvi et al., 2010). BLG can also be integrated with combined-cycle (CC) technology (BLGCC), which has potential to produce more electricity than current boiler/steam turbine systems and could even make the mill an electricity exporter (Martin et al., 2000b). Alternatively, the syngas can be used as a feedstock to produce chemicals, thereby using the pulp mill as a biorefinery (Worrell et al., 2004). Figure 10 shows a diagram of BLG for producing methanol (Naqvi et al., 2012a).

Figure 10. Schematic BLG for methanol production (Naqvi et al., 2012a)

BLG can increase energy recovery efficiency by 10 percent compared with conventional recovery technology (Cheremisinoff and Rosenfeld, 2010). In addition, it can increase the amount of electricity generated at the pulp mill by two to three times (Gebart, 2006). Aside from saving energy, BLG also can improve pulp yield and pulp quality and lower the requirement for make-up salt cake compared to the conditions with a conventional recovery boiler. However, the investment for a full-scale pressurized BLG process unit is larger than for a new conventional recovery boiler. It is estimated that the first large demonstration units will cost two to three times more than a conventional recovery boiler (Bajpai, 2010). BLG is 2-3 times as expensive in capital costs relative to a conventional recovery boiler. The capital costs for BLG were estimated at $\$ 200-500$ million (depends on different end-use configurations, among which BLGCC is the lowest one), compared to $\$ 100-150$ million for conventional recovery system, and the annual non-fuel O\&M costs were estimated at \$10-20 million (Larson et al., 2009; Larson et al., 2003). The greater investment that is required will limit the commercialization of BLG in the pulp and paper industry. The causticizing and lime kiln load increases 20 percent which can adversely impact the mill's capacity for pulp production. However, the increased causticizing load can be eliminated by including a titanate-based cyclic process called direct causticization technology (Chen and van Heiningen, 2006; Naqvi et al., 2012b; Sinquefield et al., 2010). Up to now, direct causticization technology is under development state (Chen and van Heiningen, 2006; Heiningen, 2008; ITP, 2011b). Another major disadvantage for BLG is that a new method for recovering sulfur and sodium must be installed since kraft pulping economics require nearly complete recovery of inorganic chemicals (Brown, Sept. 2012). 
To date, only small, commercial, atmospheric low-temperature BLG units have been built, e.g. Weyerhaeuser's 300 tonnes/day low pressure, entrained flow booster gasifier in New Bern, North Carolina; Georgia-Pacific's 200 tonnes/day fluidized bed steam reformer system in Big Island, Virginia; Norampac 100 tonnes/day steam reformer in Trenton, Ontario; while similar-size pressurized demonstration BLG units do not yet exist (Bajpai, 2010; Naqvi et al., 2010).

\subsubsection{Biomass Gasification}

Biomass gasification $^{3}$ is a thermo-chemical process to decompose the complex hydrocarbons of biomass into syngas that mainly consists of $\mathrm{H}_{2}$, carbon monoxide $(\mathrm{CO})$ and $\mathrm{CH}_{4}$. In most cases, some char and tars are also formed during biomass gasification, along with $\mathrm{CO}_{2}$, water, and other constituents (Ciferno and Marano, 2002). Gasification differs from combustion because it uses just 20 to 30 percent of the air or oxygen needed for complete fuel combustion. During gasification, the amount of air supplied to the gasifier is carefully controlled so that only a small portion of the fuel burns completely (Nexterra, 2012).

The generated syngas can be used as auxiliary fuel in boilers, for electricity and steam generation via gas turbines or fuel cells, or as a feedstock in the production of industrial chemicals (e.g., methanol, ethanol, acetic acid). Figure 11 shows an overview of BIGCC for the pulp and paper mill (Wetterlund, 2012). A primary advantage of biomass gasification over biomass combustion is that the power generation efficiency of a gas turbine combined-cycle system can be as much as twice the efficiency of biomass combustion processes, which uses a steam cycle alone (Ahl, 2012). Biomass gasification is a new technology although the principle of gasification has been used for decades with coal. The co-production of transport fuels by biomass gasification offers an opportunity for integrated pulp and paper mills to produce additional products onsite and increase profitability. Both the gasification and synthesis processes produce large amounts of byproduct steam or fuel gas, which can be integrated into the energy system of a pulp and paper mill (IEA, 2009).

Figure 11. Overview of BIGCC for the pulp and paper mill (Wetterlund, 2012)

An entire biomass gasification system commonly comprises biomass feeding, gasification, and gas cleanup systems. Capital and operating costs vary widely. Generally, biomass gasification is more expensive than BLG. For gasification, the biomass input to the mill would need at least to double, which might require additional investments in infrastructure (IEA, 2009). Assuming a base feedstock cost of $\$ 1.9 / \mathrm{GJ}$, the cost of production from gasification has been estimated at $6.7 \varnothing / \mathrm{kWh}$ for electricity for a $75-\mathrm{MW}$ plant. Steam costs were estimated by the U.S. National Renewable Energy Laboratory at \$14.77/t steam. Assuming a base feedstock cost of zero, the cost of production from gasification would be about $5 \notin / \mathrm{kWh}$ for electricity for a $75 \mathrm{MW}$ plant and steam costs would be $\$ 11.02 / \mathrm{t}$ steam (Bain et al., 2003).

Most of the biomass gasification technology suppliers are located in North America and Europe (Ahl, 2012). Many technology developments are in the prototype or first commercial demonstration stage now. Nexterra Systems Corp. supplied its first biomass gasification system for Kruger Products Paper Mill in New Westminster, British Columbia in 2009. This biomass

\footnotetext{
${ }^{3}$ BLG is a special case of biomass gasification, applicable only for kraft pulp mills. Given BLG has already been discussed earlier as an independent emerging technology, the biomass discussed here does not include black liquor, but only means the lignocellulosic feedstock generated in pulp and paper mills.
} 

percent of current natural gas consumption of the plant) annually for Kruger Products Paper Mill with a payback period of 3 to 3.5 years (Nexterra, 2012). Commercial-scale demonstration projects are underway at NewPage's pulp and paper mill in Wisconsin Rapits, WI, and at Flambeau River Paper in Park Falls, WI. Both of these biomass gasifier systems were supplied by ThermoChem Recovery International (TRI) (Brown, Sept. 2012).

\subsubsection{Hemicellulose Extraction before Chemical Pulping}

In kraft pulping, 50 percent of hemicellulose is removed by dissolving in the black liquor along with lignin (Hamzeh et al., 2013). Black liquor is then concentrated and burnt in chemical recovery process to recovery the energy and pulping chemicals. However, the degraded hemicelluloses in the black liquor have a negative impact on the overall energy efficiency of pulp mill because the heating value of hemicellulose is only about half of that of lignin (Amidon and Liu, 2009; Huang et al., 2010). As a result, extracting hemicellulose before pulping offers an attractive economic opportunity for the pulp and paper industry (Agenda2020, 2010). Figure 12 presents a diagram of a hemicellulose extraction process (Walton et al., 2010).

Figure 12. Diagram of a hemicellulose extraction process (Walton et al., 2010)

Hemicellulose extraction could decrease residence times in kraft pulping thus resulting in potentially increased pulping capacity or the option of using lower cooking temperatures (Jun et al., 2012). In addition, the recovery boiler and lime kiln may be off-loaded by about $20 \%$ when integrated with hemicellulose extraction technology (Mao et al., 2008). This will increase the pulp production capacity for the pulp mills that are limited by chemical recovery unit (Walton et al., 2010). A study that using kraft white liquor pre-treatment of extracting the hemicellulose from aspen chips found that the pulp yield could be maintained or even increased by $10-20 \mathrm{~g} / \mathrm{kg}$ dry wood (Jun et al., 2012). It is expected as well that this technology could substantially improve pulp mill operations (Bajpai, 2012). Hemicelluloses are hetero-polysaccharides, which contain hexosan and pentosan monomer units (Hamzeh et al., 2013). They can be used directly in polymeric form for novel industrial applications such as fiber additives, biopolymers, hydrogels, or thermoplastic xylan derivatives; or, once hydrolyzed, they can serve as a source of sugars for fermentation to fuels, such as ethanol or chemicals (Al-Dajani and Tschiner, 2008). These process benefits and biofuel possibilities are strong drivers for the development of wood hemicellulose extraction technologies for kraft mills.

In recent years, the interest in the extraction of hemicellulose prior pulping has greatly increased. Several research groups are exploring various pre-treatments of lignocellulosic materials including autohydrolysis, hydrothermolysis, and aqueous liquefaction (Al-Dajani and Tschiner, 2008; Jun et al., 2012). Pre-extraction before pulping using water/steam as the only solvent has been investigated because it is cheap and environmentally friendly and results in simpler downstream processes compared to dilute acid and alkaline pre-hydrolysis (Walton et al., 2010). Other methods for hemicellulose extraction include mild alkaline solutions with or without addition of cations such as $\mathrm{Na}, \mathrm{K}, \mathrm{Li}$ and borate low temperature, organosolv fractionation, supercritical carbon dioxide, ionic liquids, and microwave heat-fractionation (Bajpai, 2012). Of these methods, pretreatment of lignocellulosic materials with water has been demonstrated as an excellent option for the extraction of hemicellulose since no chemicals other than water are involved (Al-Dajani et al., 2009). The 
study of near-neutral hemicellulose extraction shows that less steam is produced in the recovery boiler because some of the energy content in the wood is contained in the by-products and steam is required in the processing. In addition, considerable sulfuric acid is required for the hydrolysis step in the process and lime is required for neutralization of the extract (Lundberg et al., 2012; Mao et al., 2008; Mora et al., 2011; Yoon et al., 2011b).

Removal of hemicelluloses from wood chips as a pre-treatment step is presently being practiced commercially in the production of dissolving pulps (Bajpai, 2012; Jun et al., 2012). While for the production of chemical pulps, hemicellulose extraction is currently under pilot stage (Brown, Sept. 2012). Hemicellulose extraction before pulping is being built for demonstration at Old Town in Maine, U.S. (Agenda2020, 2010). It was reported that hemicellulose extraction before pulping could result in pulps that refine difficultly and forms a weaker paper than obtained pulps from unextracted raw materials for soda-AQ (anthraquinone) pulping of rice straw (Jahan et al., 2012). Hotwater extraction was found to negatively impact some pulp properties including decreases in burst and tensile indices while addition of chitosan and cationic starch could improve the strength properties. However, no distinct differences in tear index were observed, indicating that the fiber strength remains unaffected, but the inter-fiber bonding decreases with extraction (Hamzeh et al., 2013). There is a trade-off in how much hemicellulose is to be extracted without adversely affecting the amount and quality of the pulp to be made, which should be studied further before commercialized.

\subsubsection{LignoBoost}

LignoBoost is a new technology that extracts lignin from black liquor with the potential to create new revenues for pulp mills. The technology uses $\mathrm{CO}_{2}$ to lower the $\mathrm{pH}$ of the black liquor which causes precipitation of lignin. The precipitate is then dewatered using a filter press. LignoBoost then overcomes conventional filtering and sodium separation problems by re-dissolving the lignin in spent wash water and acid. The resulting slurry is once again dewatered and washed with acidified wash water to produce virtually pure lignin cakes (see Figure 13) (Metso, 2012). An estimated 25 to 50 percent of the lignin can be removed from black liquor using this process (IEA, 2009).

Lignin is an outstanding biofuel with high heat value. It can be used in a power plant boiler, recovery boiler, or lime kiln to replace fossil fuel (SETIS, 2011). Potential savings from using lignin in a lime kiln are as much as 50 liters of fuel oil per tonne of pulp. Lignin can also be used as the raw material for making chemicals instead of petroleum-based products, which makes it a very interesting substance for the chemical industry where many companies are looking for renewable raw materials for manufacturing food, dyes, plastics, pharmaceuticals, and other products. Activated carbon is another product with potential to be made from lignin (Innventia, 2012). There are successful trials using lignin to make carbon fibers. Pulp mills can derive additional income from using lignin as fuel and selling it for further refining.

LignoBoost technology was first developed by researchers at Innventia and Chalmers University of Technology. A demonstration plant with a capacity of 6,000 to 10,000 t lignin/year is integrated into the pulping process of Nordic Paper in Sweden in 2007 (Innventia, 2012). In 2008, Metso purchased the LignoBoost technology in an agreement with Innventia that includes further development, design tool improvement, and industrial scaling-up. In 2011, Metso announced the sale of the first commercial LignoBoost technology to Domtar pulp mill in North Carolina. This LignoBoost plant will be integrated with the Plymouth North Carolina pulp mill and will be in 
commercial operation in 2013 (Metso, 2012). The IEA estimates that if the surplus lignin (i.e., the lignin that is not used by the mill itself but is sold to the market) sells for more than US\$ 5.5/GJ, this process would generate additional profits for the mill (IEA, 2009).

Figure 13. LignoBoost in chemical pulping plant (Metso, 2012)

\subsubsection{Other Biorefinery Concepts}

The pulp and paper industry is currently undergoing industrial transformation and upgrading. Many mills are no longer producing only pulp and/or paper but are also manufacturing other products that can increase both their profitability and overall energy efficiency. These mills are functioning as biorefineries in addition to their traditional manufacturing (Jönsson et al., 2011). A biorefinery can use all types of biomass available at a pulp and/or paper mill, including debarking waste, waste wood chips, forest residues, paper mill residues, and sludge generated from the pulping and papermaking process (Mäkinen et al., 2011). Even for the waste paper, it was reported that it can be used for bioethanol production (Wang et al., 2012). By integrating biorefinery operations with the pulp and papermaking process, the industry can produce a wide variety of materials, from chemicals to fuels, in addition to paper products (CEPI, 2009).

According to the IEA Bioenergy Task 42, biorefining is the sustainable processing of biomass into a spectrum of marketable products (e.g., chemicals, materials, food and feed) and energy products (e.g., bioethanol, biodiesel, and synthetic biofuels). The biorefinery can be a concept, a facility, a process, a plant, or even a cluster of facilities (IEA, 2010b). The biorefinery concept also embraces a wide range of conversion technologies that can separate biomass resources into their building blocks (carbohydrates, proteins, triglycerides, etc.), which can then be converted to value-added products, biofuels, and chemicals (Cherubini, 2010). Biorefinery technology pathways are typically categorized as chemical (extraction, fractionation, synthesis, etc.), biochemical (digestion, carbohydrate, fermentation, etc.) and thermochemical (pyrolysis, gasification, torrefaction, etc.) (Stawicki and Read, 2010).

Biorefining is similar in concept to the petroleum refining except that local, renewable biomass materials are the feedstock rather than crude oil. Biorefinery concepts for chemical pulp mills have been extensively investigated, but recycled fiber biorefineries have not yet been fully investigated. Most of the large paper recycling and deinking mills already produce some bioenergy and other bioproducts from their reject materials but do not yet produce liquid biofuels or biochemicals (Stawicki and Read, 2010). Figure 14 shows a flow diagram of the forest based biorefinery.

Figure 14. Flow diagram of integrated forest biorefinery (Amidon and Liu, 2009)

The pulp and paper industry is working with the chemical and energy sectors to develop biorefineries in Europe, Canada and the U.S., and biorefinery roadmaps have been developed in these regions (IEA, 2009). A number of large programs under the European Union's Seventh Framework Programme (FP7) for research and innovation focus on developing biorefinery and related technologies. Work is currently being done to further develop of second-generation lignocellulosic biofuels (SETIS, 2011). Some pre-commercial, industrial-scale demonstration plants are producing cellulosic ethanol. In 2011, the Mossi \& Ghisolfi Group (Chemtex) started 
building a commercial-scale 50 million liters/year cellulosic ethanol production facility in Crescentino, Italy (EBTP, 2012b). A first large-scale bio-dimethyl ether (DME) plant in connection to a pulp mill is currently being constructed in Sweden (SETIS, 2011). However, the technological and economic challenges must be overcome before commercialization of these biorefinery technologies.

Table 7 shows seven promising biorefinery paths from European Industrial Bioenergy Initiative, which also shows the final products from each biorefinery path. Because of the scale of investment needed and the risks involved (technology, feedstock \& end product prices, regulatory framework evolution), financing the latest stages of development of innovative bioenergy technologies is a major obstacle for large scale industrial deployment of these technologies. However, all the seven promising biorefinery paths are expected to be first commercialized by 2020 (EBTP, 2011, 2012a). It presents the general information about these seven biorefinery paths, including preliminary estimates of capital cost, the status of development, and main technology challenges. Further information such as brief description of each path, examples of ongoing pilot/demonstration projects, and technical challenges for all value chains can be found at (EBTP, 2011, 2012a).

Table 7. The most promising biorefinery chains under development (EBTP, 2011)

\section{Conclusions}

This paper reviews 25 emerging energy-efficiency technologies for the pulp and paper industry from the perspective of mid- and long-term energy-efficiency improvement by filling the gap in the information to assist engineers, researchers, investors, policy makers, pulp and/or paper companies, and other interested parties. All the emerging energy-efficiency technologies presented in the paper are alternatives to traditional production of pulp and paper or production of conventional and/or new raw materials used in other manufacturing sectors, e.g., chemicals, food, dyes, plastics, and pharmaceuticals. It is likely that no single technology described here will be the best or only solution; instead, a portfolio of technologies should be developed and deployed to address the increasing energy consumption and $\mathrm{CO}_{2}$ emissions for the pulp and paper industry.

Directed green liquor utilization pulping, steam cycle washing, recycled paper fractionation, and surfactant spray deinking are demonstrated emerging pulping technology which will increase the waste resources utilizing efficiency for pulping process. High consistency forming is one of the most attractive opportunities to dramatically cut water and energy consumption in papermaking process. Although dry sheet forming is an interesting technology for production of regular paper grades as no water is involved, it might not to be adopted widely in the near future as it only applied to produce personal care and some specialty products up to date. Other emerging pulping and papermaking technologies have a potential to be employed by the paper industry generally as their commercialization. Regarding new paper drying technologies, gas-fired dryer is a revolutionary drying technology for enhancing paper drying performance and has a potential to replace steam-heated cylinders if natural gas were accessible for paper mill. Condebelt drying is a new technology that still need further develop to make it suited for other paper grades beyond paperboard. Boost drying and microwave drying technology will be an alternative measure for 
improving multicylinder drying efficiency, however, both of them could not substitute multicylinder totally in the dryer section of paper machine.

Biological technology such as biological pre-treatment, black liquor and/or biomass gasification, and other biorefineries are very promising and interesting emerging technologies because they are environmental friendly besides improving energy efficiency for the pulp and paper industry. Moreover, biorefineries could also extend the industrial chain and boost added value for the pulp and paper sector. However, the great capital investment in biorefineries might impede their commercialization. Nanotechnology is another recently emerged science-based new technology that could benefit the pulp and paper industry extensively. Increased efficiency of nanotechnology in modern paper industry will greatly reduce costs and use of resources (e.g. wood, water, and energy), thereby abating the associated $\mathrm{CO}_{2}$ emissions and related environmental impacts markedly.

The aforementioned emerging technologies for pulp and paper industry would help to identify new R\&D projects and potential technologies for market transformation activities. It could also offer new insights into technology development and energy efficiency potentials. However, aggressive $\mathrm{R} \& \mathrm{D}$ is still needed to address issues and barriers confronting the emerging technologies. The major barriers prevent new technology adoption and penetration are high initial capital investment, long payback period, and low cost-effectiveness. Some remarks have also to be made. First, as can be seen from the information presented in this paper, most of the technologies described in this paper have an energy or carbon penalty associated with their operation. Further research is required to improve and optimize these technologies in order to minimize their energy penalties. Additionally, for some technologies, little information was available other than that provided by the developers of the technology developers. Independent studies and validation of the fundamentals and operation of these emerging technologies would be helpful to the private and public sectors as well as academia. Finally, it should be noted that the purpose of this paper is solely informational.

\section{Acknowledgments}

This work was supported by the China Sustainable Energy Program of the Energy Foundation and Dow Chemical Company (through a charitable contribution) through the U.S. Department of Energy under Contract No. DE-AC02-05CH11231. We are thankful to Ron Brown from Agenda 2020 Technology Alliance, Reid Miner and Barry Malmberg from National Council for Air and Steam Improvement, and Bhima Sastri from the U.S. Department of Energy for their valuable comments on the earlier version of this study. We also would like to thank the four anonymous reviewers for their helpful comments and suggestions.

\section{References}

Abbasi, G.Y., Abbassi, B.E., 2004. Environmental assessment for paper and cardboard industry in Jordan - a cleaner production concept. Journal of Cleaner Production 12, 321-326.

Abou-Elela, S.I., Nasr, F.A., Ibrahim, H.S., Badr, N.M., Askalany, A.R.M., 2008. Pollution prevention pays off in a board paper mill. Journal of Cleaner Production 16, 330-334.

Adnan, S., Hoang, M., Bolto, H.T.W.B., Z. L. Xie, 2010. Recent trends in research, development and application of membrane technology in the pulp and paper industry. Appita 63, 235-241. 
Agenda2020, 2010. Forest Products Industry Technology Roadmap. Agenda 2020 Technology Alliance.

Ahl, D., 2012. Wisconsin Biorefining Development Initiative. Biorefining Process - Biomass Gasification. Available at. http://www.biorefine.org (accessed April 10, 2012).

Ahrens, F.W., 2003. Application of a Device for Uniform Web Drying and Preheating Using Microwave Energy Institute of Paper Science and Technology (IPST) at Georgia Tech, Program/Project Identification No.: DE-FC07-00ID13872, Atlanta, Georgia.

Akhtar, M., Swaney, R., Horn, E., Lentz, M., Scott, G.M., Black, C.C., Houtman, J., 2007. Method for Producing Pulp. Patent No.: US 7306698 B2.

Al-Dajani, W.W., Tschiner, U.W., 2008. Pre-extraction of hemicelluloses and subsequent kraft pulping Part I: Alkaline extraction. TAPPI 91, 3-8.

Al-Dajani, W.W., Tschirner, U.W., Jensen, T., 2009. Pre-extraction of hemicelluloses and subsequent kraft pulping Part II: Acid-and autohydrolysis. TAPPI 92, 30-37.

Alsema, E.A., 2001. ICARUS-4: Sector sutdy for the paper and board industry and the graphical industry. Department of Science, Technology and Society, Utrecht University, The Netherlands.

Amidon, T.E., Liu, S., 2009. Water-based woody biorefinery. Biotechnology Advances 27, 542-550.

Avşar, E., Demirer, G.N., 2008. Cleaner production opportunity assessment study in SEKA Balikesir pulp and paper mill. Journal of Cleaner Production 16, 422-431.

B\&W, 2009. Dual Pressure Reheat Recovery Boiler. Babcock \& Wilcox Power Generation Group, Inc.(B\&W), Available at. http://www.babcock.com/library/pdf/E1013208.pdf (accessed August 9, 2012).

Bain, R.L., Amos, W.A., Downing, M., Perlack, R.L., 2003. Highlights of Biopower Technical Assessment: State of the Industry and the Technology. National Renewable Energy Laboratory.

Bajpai, P., 2010. Environmentally Friendly Production of Pulp and Paper. John Wiley \& Sons, Hoboken, New Jersey.

Bajpai, P., 2012. Biotechnology for Pulp and Paper Processing. Springer, New York.

Beck, D., 2006. Development of A Continuous Process for Displacem ent Dewatering, Final Report. U.S. DOE project DE-FC36-01GO10622. Voith Paper, Appleton, Wisconsin.

Bhattacharjee, C., Bhattacharya, P.K., 2006. Ultrafiltration of black liquor using rotating disk membrane module. Separation and Purification Technology 49, 281-290.

Bhattacharjee, S., Datta, S., Bhattacharjee, C., 2006. Performance study during ultrafiltration of Kraft black liquor using rotating disk membrane module. Journal of Cleaner Production 14, 497-504.

Bjork, M., Sjogren, T., Lundin, T., Rickards, H., Kochesfahani, S., 2005. Partial borate autocausticizing trial increases capacity at Swedish mill. TAPPI 88, 15-19.

Brown, R., Sept. 2012. Personal communication with Ron Brown from Agenda 2020 Technology Alliance.

Confederation of European Paper Industries (CEPI), 2009. CEPI Europe's pulp and paper industry in 2020 and beyond. Carta \& Cartiere, 14-18.

Chemrec, 2012. A gasification technology inherently more efficient. Available at. http://www.chemrec.se/ (accessed April 10, 2012).

Chen, X., van Heiningen, A.R.P., 2006. Kinetics of the direct causticizing reaction between sodium carbonate and sodium trititanate. Journal of Pulp and Paper Science 32, 245-251.

Cheremisinoff, N.P., Rosenfeld, P.E., 2010. Handbook of Pollution Prevention and Cleaner Production Vol. 2: Best Practices in the Wood and Paper Industries, $1^{\text {st }}$ ed. Elsevier, New York.

Cherubini, F., 2010. The biorefinery concept: Using biomass instead of oil for producing energy and chemicals. Energy Conversion and Management 51, 1412-1421.

Chudnovsky, $\quad$ Y., $2011 . \quad$ High Efficiency Gas-Fired Drum Dryer for Food Processing Applications. California Energy Commission, PIER Industrial/Agricultural/Water EndUse Energy Efficiency Program. CEC-500-2010-043.

Chudnovsky, Y., J.DiGiacomo, 2006. Advanced High-Efficiency and Low Emission Gas-Fired Drum Drying Technology, 2006 TAPPI PLACE Conference. TAPPI. 
Chudnovsky, Y., Kozlov, A., Sherrow, L., 2004. Laboratory Development of a High Capacity Gas-Fired Paper Dryer, Final Technical Report. GTI/DOE/SMP/GRI-61134/80042/30797. Gas Technology Institute - Energy Utilization Center, Des Plaines, IL.

Cichoracki, T., Gullichsen, J., Paulapuro, H., 2001. High consistency forming: A new concept. TAPPI 84.

Ciferno, J.P., Marano, J.J., 2002. Benchmarking Biomass Gasification Technologies for Fuels, Chemicals and Hydrogen Production. Prepared for U.S. Department of Energy, National Energy Technology Laboratory.

Compere, A.L., 2006. Increasing Yield and Quality of Low-Temperature, Low-Alkali Kraft Cooks with Microwave Pretreatment, DOE Industrial Technologies Program, Atlanta, Georgia.

Cui, Z., yannan, H., Hong, J., Ismail, Z.Z., 2011. Life cycle assessment of coated white board: a case study in China. Journal of Cleaner Production 19, 1506-1512.

Dafinov, A., Font, J., Garcia-Valls, R., 2005. Processing of black liquors by UF/NF ceramic membranes. Desalination 173, 83-90.

de Beer, J., Worrell, E., Block, K., 1998. Long-term energy-efficiency improvements in the paper and board industry. Energy 23, 21-42.

Delozier, G., Zhao, Y., Deng, Y., White, D., Zhu, J., Prein, M., 2005. Laboratory- and mill-scale study of surfactant spray flotation deinking. TAPPI 88, 25-30.

Deng, Y., Zhu, J., 2004. Surfactant spray: A novel technology to improve flotation deinking performance. Final report. Institute of Paper Science and Technology (IPST), Georgia Institute of Technology, US. DOE Contract No.:DE-FC07-00ID13879.

Dias, A.C., Arroja, L., 2012. Comparison of methodologies for estimating the carbon footprint - case study of office paper. Journal of Cleaner Production 24, 30-35.

Dillard, D.S., 1998. Membrane technology applications in the pulp and paper industry. National Council of the Paper Industry for Air and Stream Improvement, Inc. (NCASI), Technical Bulletin No. 763. Research Triangle Park, NC.

European Biofuels Technolgoy Platform (EBTP), 2011. Boosting the contribution of Bioenergy to the EU climate and energy ambitions - Implementation plan for 2010-2012. European Industrial Bioenergy Initiative (EIBI).

European Biofuels Technolgoy Platform (EBTP), 2012a. European Industrial Bioenergy Initiative (EIBI). Available at. http://www.biofuelstp.eu/eibi.html (accessed April 10, 2012).

European Biofuels Technolgoy Platform (EBTP), 2012b. M\&G (Chemtex)/Novozymes commercial scale cellulosic ethanol plant in Crescentino. Available at. http://www.biofuelstp.eu/cell_ethanol.html\#ce1 (accessed April 10, 2012).

European Commission (EC),, 2001. Reference Document on Best Available Techniques in the Pulp and Paper Industry. Available at: http://eippcb.jrc.es/reference Integrated Pollution Prevention and Control (IPPC), Brussels.

European Commission (EC),, 2012. Best Available Techniques (BAT) Reference Documents for Production of Pulp, Paper, and Board - Draft2. European Integrated Pollution Prevention and Control Bureau (EIPPCB), Brussels.

ECOTARGET, 2009. New and innovative processes for radical changes in the European pulp \& paper industry - Publishable Final Activity Report, ECOTARGET 500345.

FitzPatrick, M., Champagne, P., Cunningham, M.F., Whitney, R.A., 2010. A biorefinery processing perspective: Treatment of lignocellulosic materials for the production of value-added products. Bioresource Technology 101, 8915-8922.

Focus on Energy (FOE), 2005. Pulp and Paper Energy Best Practice Guidebook. Madison, Wisconsin.

Fornell, R., Berntsson, T., 2012. Process integration study of a kraft pulp mill converted to an ethanol production plant - Part A: Potential for heat integration of thermal separation units. Applied Thermal Engineering 35, 81-90.

Gabbrielli, R., Medeot, C., Miconi, D., 2006. Energy saving in the tissue industry: technical and economic aspects of a case study. Journal of Cleaner Production 14, 185-193. 
Gebart, R., 2006. Improvement Potential in Chemical Pulping: Black Liquor Gasification, IEA-WBCSD Workshop on Energy Efficient Technologies and $\mathrm{CO}_{2}$ Reduction Potentials in the Pulp and Paper Industry, Paris, France.

Ghosh, A.K., 2009. A Systematic Approach to Optimise Dryer Performance and Energy Savings-Case Studies, TAPPI PaperCon'09 Conference. TAPPI, St. Louis, Missouri, USA.

Girard, R.D., Hoddenbagh, J.M.A., Petit-Conil, M., 2006. Enzymatic Treatment of Hardwood Chips Reduces Refining Energy in Mechanical Pulping, PAPTAC 92 ${ }^{\text {nd }}$ Annual Meeting, Montreal, Canada.

Gosselink, R.J.A., de Jong, E., Guran, B., Abächerli, A., 2004. Co-ordination network for ligninstandardisation, production and applications adapted to market requirements (EUROLIGNIN). Industrial Crops and Products 20, 121-129.

Graves, J.K., Albrecht, M.J., Osborne, S.R., 2007. Dual pressure recovery boiler. Babcock \& Wilcox Power Generation Group, Inc.

Haase, C., 2005. BoostDryer-New higher-performance drying technology for improved paper quality. twogether - Paper Technology Journal. Voith Paper Customer Magazine, 44-47.

Hamzeh, Y., Ashori, A., Khorasani, Z., Abdulkhani, A., Abyaz, A., 2013. Pre-extraction of hemicelluloses from bagasse fibers: Effects of dry-strength additives on paper properties. Industrial Crops and Products 43, 365-371.

Hasanbeigi, A., Price, L., Lin, E., 2012. Emerging energy-efficiency and $\mathrm{CO}_{2}$ emission-reduction technologies for cement and concrete production: A technical review. Renewable and Sustainable Energy Reviews 16, 6220-6238.

Hasanbeigi, A.; Arens, M.; Price, L., 2014. Alternative emerging ironmaking technologies for energyefficiency and carbon dioxide emissions reduction: A technical review. Renewable and Sustainable Energy Reviews 33, 645-658.

Heiningen, A.v., 2008. Mill Integration-Pulping, Steam Reforming and Direct Causticization for Black Liquor Recovery, Final report. U.S. DOE project: DE-FC26-02NT41493, Orono, Maine.

Hellsmark, H., 2011. Unfolding the formative phase of gasified biomass in the European Union: The role of system builders in realising the potential of second-generation transportation fuels from biomass, Department of Energy and Environment. Chalmers University of Technology, Göteborg, Sweden.

Hertl, E., 2008. Energy Saving by Novel De-inking Technologies, Proceedings COST Strategic Workshop - Improving Energy Efficiency in Papermaking, Amsterdam, The Netherlands.

Heyne, S., Harvey, S., 2012. Assessment of the energy and economic performance of second generation biofuel production processes using energy market scenarios. Applied Energy, In Press, http://dx.doi.org/10.1016/j.apenergy.2012.03.034.

Hicks, T.E., 2011. Integrating a Reheat Steam Cycle Power or Recovery Boiler into an Existing Pulp Mill, TAPPI Pulping, Engineering, Environmental, Recycling and Sustainability Conference. TAPPI, Portland, Oregon.

Hicks, T.E., Stirgwolt, W.R., Monacelli, J.E., 2009. Recovery Boiler Reheat Steam Cycle, 2009 TAPPI Engineering, Pulping \& Environmental Conference, Memphis, Tennessee.

Holmqvist, A., Wallberg, O., Jönsson, A.S., 2005. Ultrafiltration of kraft black liquor from two Swedish pulp mills. Chemical Engineering Research and Design 83, 994-999.

Hong, G.-B., Ma, C.-M., Chen, H.-W., Chuang, K.-J., Chang, C.-T., Su, T.-L., 2011. Energy flow analysis in pulp and paper industry. Energy 36, 3063-3068.

Houtman, C., Horn, E., 2011. Pilot trials of hemicelluloses extraction prior to thermomechanical pulp production: Part 1. TAPPI 94, 21-28.

Huang, H.-J., Ramaswamy, S., Al-Dajani, W.W., Tschirner, U., 2010. Process modeling and analysis of pulp mill-based integrated biorefinery with hemicellulose pre-extraction for ethanol production: A comparative study. Bioresource Technology 101, 624-631.

Hunter, M., Stuart, D., Bursey, R., Kochesfahani, S.H., Tran, H.N., Bair, C.M., 2001. Mill Trial on Partial Autocausticizing using Borate, 2001 TAPPI International Engineering Conference. TAPPI, San Antonio, Texas, USA. 
International Energy Agency (IEA), 2007. Tracking Industrial Energy Efficiency and $\mathrm{CO}_{2}$ Emissions. Paris, France.

International Energy Agency (IEA), 2009. Energy Technology Transitions for Industry - Strategies for the Next Industrial Revolution. Paris, France.

International Energy Agency (IEA), 2010a. Energy Technology Perspectives - Scenarios and Strategies to 2050. Paris, France.

International Energy Agency (IEA), 2010b. IEA Bioenergy Task 42 on Biorefinery. Paris, France.

International Energy Agency (IEA), 2011. Energy Transition for Industry: India and the Global Context. Paris, France.

Innventia, 2012. The LignoBoost Process. Available at. http://www.innventia.com (accessed April 10, 2012).

Industrial Technologies Progarm (ITP), 2006a. Application of a Device for Uniform Web Drying and Preheating Using Microwave Energy. U.S. Department of Energy. Contract No.: \#DE-FC0700ID13872, Washington, D.C.

Industrial Technologies Progarm (ITP), 2006b. Fibrous Fillers to Manufacture Ultra-High Ash/Performance Paper. U.S. Department of Energy. Contract No.: \#FC36-03ID14439, Washington, D.C.

Industrial Technologies Progarm (ITP), 2006c. Forest Products Technologies: Public Private Partnerships Produce R\&D Results. U.S. Department of Energy, Washington, D.C.

Industrial Technologies Progarm (ITP), 2006d. Laboratory Development of High-capacity, Gas-fired Paper Dryer - Novel Combustion System Can Increase the Efficiency of the Drying Proces. U.S. Department of Energy. Contract No.: \# DE-FC36-01GO10621, Washington, D.C.

Industrial Technologies Progarm (ITP), 2006e. Steam Cycle Washer for Unbleached Pulp. Enhancing Industry Profitability by Reducing Energy Costs, Increasing Product Quality, and Reducing Environmental Impact. U.S. Department of Energy. Contract No.: DE-FC36-04GO14304, Washington, D.C.

Industrial Technologies Progarm (ITP), 2007a. Increasing Yield and Quality of Low-temperature, Lowalkali Kraft Cooks with Microwave Pretreatment - Minimizing the Effect of Variations in Fiber Sources Prior to Pulping. U.S. Department of Energy, Washington, D.C.

Industrial Technologies Progarm (ITP), 2007b. Surfactant Spray: A Novel Technology to Improve Flotation Deinking Performance. U.S. Department of Energy. Contract No.: \# DE-FC07-00ID13879, Washington, D.C.

Industrial Technologies Progarm (ITP), 2010. Energy Technology Solutions: Public Private Partnerships Transforming Industry. U.S. Department of Energy, Washington, D.C.

Industrial Technologies Progarm (ITP), 2011a. Highly Energy Efficient D-GLU (Directed Green Liquor Utilization) Pulping. U.S. Department of Energy, Washington, D.C.

Industrial Technologies Progarm (ITP), 2011b. IMPACTS: Industrial Technologies Program: Summary of Program Results for CY2009. U.S. Department of Energy, Washington, D.C.

Jönsson, A.-S., Wallberg, O., 2009. Cost estimates of kraft lignin recovery by ultrafiltration. Desalination 237, 254-267.

Jönsson, J., Ruohonen, P., Michel, G., Berntsson, T., 2011. The potential for steam savings and implementation of different biorefinery concepts in Scandinavian integrated TMP and paper mills. Applied Thermal Engineering 31, 2107-2114.

Jaccard/Willis, 1996. Industrial Energy End-Use Analysis \& Conservation Potential in Six Major Industries in Canada, Chapter 3 - Pulp and Paper. Prepared for Natural Resources Canada. Prepared by MK Jaccard and Associates \& Willis Energy Services Ltd, Ottawa, Canada.

Jahan, M.S., Shamsuzzaman, M., Rahman, M.M., Moeiz, S.M.I., Ni, Y., 2012. Effect of pre-extraction on soda-anthraquinone (AQ) pulping of rice straw. Industrial Crops and Products 37, 164-169.

Jiang, B., 1997. Experimental Investigation of a Batch, Fluidizing Drying Forming Process, Department of Chemical Engineering. Queen's University, Kingston, Ontario, Canada. 
Jun, A., Tschirner, U.W., Tauer, Z., 2012. Hemicellulose extraction from aspen chips prior to kraft pulping utilizing kraft white liquor. Biomass and Bioenergy 37, 229-236.

Karner, N., Herzog, F., 2008. New Drying Technology for Higher Drying Rates and Improved Product Quality, 2008 TAPPI PaperCon Conference. TAPPI, Dallas, Texas, USA.

Kemppainen, K., Körkkö, M., Haapala, A., Illikainen, M., Niinimäki, J., 2010. Benefits of Fractionation during pulping in Deinking, 2010 TAPPI Peers Conference and 9th Research Forum on Recycling. TAPPI, Norfolk, Virginia, USA.

Kemppainen, K., Körkkö, M., Niinimäki, J., 2011. Fractional pulping of toner and pigment-based inkjet ink printed papers - ink and dirt behavior. BioResources 6, 2977-2989.

Kinstrey, R.B., White, D., 2006. Pulp and Paper Industry Energy Bandwidth Study. Report for the American Institute of Chemical Engineers (AIChE). Prepared by: Jacobs Engineering, Greenville, South Carolina \& Institute of Paper Science and Technology (IPST) at Georgia Institute of Technology, Atlanta, Georgia.

Kochesfahani, S.H., Bair, C.M., 2002. Partial Borate Autocausticizing Technology, 2002 TAPPI Fall Technical Conference. TAPPI, San Diego, California, USA.

Kong, L., Hasanbeigi, A., Price, L., Liu, H., 2015. Energy conservation and CO2 mitigation potentials in the Chinese pulp and paper industry (in Press). Resources, Conservation and Recycling, http://dx.doi.org/10.1016/j.resconrec.2015.05.001

Korkko, M., Bussini, D., Laitinen, O., Elegir, G., Niinimaki, J., 2011. True-neutral Fractional Deinking for Flexographic and Offset Newsprints, $65^{\text {th }}$ Appita Annual Conference. Appita, Rotorua, New Zealand, pp. 23-30.

Kramer, K.J., Masanet, E., Xu, T., Worrell, E., 2009. Energy Efficiency Improvement and Cost Saving Opportunities for the Pulp and Paper Industry, An ENERGY STAR Guide for Energy and Plant Managers. Lawrence Berkeley National Laboratory, LBNL-2268E, Berkeley, California.

Kramer, K.J., Masanet, E., Worrell, E., 2010. Energy Efficiency Opportunities in the U.S. Pulp and Paper Industry. Energy Engineering 107, 21-50.

Larson, E.D., Consonni, S., Katofsky, R.E., Iisa, K., W. James Frederick, J., 2009. An Assessment of Gasification-Based Biorefining at Kraft Pulp and Paper Mills in the United States, Part B: Results. TAPPI, 27-35.

Larson, E.D., Consonni, S., Katofsky., R.E., 2003. A Cost-Benefit Assessment of Biomass Gasification Power Generation in the Pulp and Paper Industry. Final Report. Princeton University.

Lee, H.L., Yuon, H.J., Jung, T.M., 2000. Improvement of linerboard properties by Condebelt drying. TAPPI 83.

Leon, J., Aliaga, C., Boulougouris, G., Hortal, M., Marti, J.L., 2014. Quantifying GHG emissions savings potential in magazine paper production: a case study on supercalendered and light-weight coated papers. Journal of Cleaner Production In Press, Corrected Proof.

Li, X., Cai, Z., Horn, E., Winandy, E.E., 2011. Oxalic acid pretreatment of rice straw particles and loblolly pine chips: Release of hemicellulosic carbohydrates. TAPPI 94, 41-45.

Lucia, L.A., 2005. Novel Pulping Technology: Directed Green Liquor Utilization (D-GLU) Pulping. Final Technical Report for the US Department of Energy, DE-FC36-01GO10626 Georgia Institute of Technology, Institute of Paper Science and Technology, Atlanta, GA.

Lucia, L.A., 2006. Highly Energy Efficient Directed Green Liquor Utilization (D-GLU) Pulping, DOE Industrial Technologies Program, Atlanta, Georgia.

Lundberg, V., Axelsson, E., Mahmoudkhani, M., Berntsson, T., 2012. Process integration of near-neutral hemicellulose extraction in a Scandinavian kraft pulp mill - Consequences for the steam and $\mathrm{Na} / \mathrm{S}$ balances. Applied Thermal Engineering 43, 42-50.

Mäkinen, T., Alakangas, E., Kauppi, M., 2011. BioRefinery Yearbook 2011. Tekes, Helsinki, Finland.

Manninen, J., Puumalainen, T., Talja, R., Pettersson, H., 2002. Energy aspects in paper mills utilising future technology. Applied Thermal Engineering 22, 929-937. 
Mao, H., Genco, J.M., Yoon, S.H., Heiningen, A.v., Pendse, H., 2008. Technicaleconomicevaluation of ahardwoodbiorefinery using the "Near-Neutral" hemicellulose pre-extraction process. Journal of Biobased Materials and Bioenergy 2, 177-185.

Martin, N., Anglani, N., Einstein, D., Khrushch, M., Worrell, E., Price, L., 2000a. Opportunities to Improve Energy Efficiency and Reduce Greenhouse Gas Emissions in the U.S. Pulp and Paper Industry. Lawrence Berkeley National Laboratory, LBNL-46141, Berkeley, California.

Martin, N., Worrell, E., Ruth, M., Price, L., Elliott, R.N., Shipley, A.M., Thorne, J., 2000b. Emerging energy-efficient industrial technologies. Lawrence Berkeley National Laboratory, LBNL-46990, Berkeley, Carlifornia.

Mathur, V., 2006. GRI's Fibrous Filler Technology. Presentation by G.R. International, Available at: http://www1.eere.energy.gov/manufacturing/industries_technologies/forest/pdfs/mathur.pdf.

Metso, 2012. New process extracts lignin from pulp mill black liquor: LignoBoost. Available at. http://www.metso.com (accessed April 10, 2012).

Monacelli, J.E., Hicks, T.E., Hiner, L.A., Osborne, S.L., 2008. Enhanced steam cycle utilizing a dual pressure recovery boiler with reheat. Babcock \& Wilcox Power Generation Group, Inc., U.S.

Mora, V., Mahmouddkhani, M., Berntsson, T., 2011. Scandinavian Hardwood Biorefinery Using "NearNeutral" Hemicelluloses Pre-extraction Energy Efficiency Measures. Chemical Engineering Transactions 25, 411-416.

Moshkelani, M., Marinova, M., Perrier, M., Paris, J., 2012. The forest biorefinery and its implementation in the pulp and paper industry: Energy overview. Applied Thermal Engineering, In Press.

Muehlethaler, E., Starkey, Y., Salminen, R., Harding, D., 2008. Steam Cycle Washer for Unbleached Pulp - Final Report. DE-FC36-04GO14304. Port Townsend Paper Corporation, $21^{\text {st }}$ Century Pulp and Paper, and Idaho National Laboratory, Port Townsend, WA.

Mujumdar, A.S., 2006. Handbook of Industrial Drying, $3^{\text {rd }}$ ed. CRC Press, New York.

Naqvi, M., Yan, J., Dahlquist, E., 2010. Black liquor gasification integrated in pulp and paper mills: A critical review. Bioresource Technology 101, 8001-8015.

Naqvi, M., Yan, J., Dahlquist, E., 2012a. Bio-refinery system in a pulp mill for methanol production with comparison of pressurized black liquor gasification and dry gasification using direct causticization. Applied Energy 90, 24-31.

Naqvi, M., Yan, J., Dahlquist, E., 2012b. Synthetic gas production from dry black liquor gasification process using direct causticization with $\mathrm{CO}_{2}$ capture. Applied Energy 97, 49-55.

National Council for Air and Stream Improvement (NCASI), 2008. The Greenhouse Gas and Carbon Profile of the U.S. Forest Products Sector. Research Triangle Park, North Carolina. Special Report No. 08-05.

New Energy and Industrial Technology Development Organization (NEDO), 2008. Janpanese Technologies for Energy Savings/GHG Emissions Reduction (2008 Revised Edition). Kanagawa, Japan, pp. 157-169.

Nexterra, 2012. Nexterra's Gasification Technology. Available at. http://www.nexterra.ca (accessed April 10, 2012).

OIT, 1999. Forest Products, Project Fact Sheet Impulse Drying of Paper. Office of Industrial Technologies (OIT), U.S. Department of Energy, Washington, D.C. .

Office of Industrial Technologies (OIT), 2001a. Increasing Yield and Quality of Low-temperature, Lowalkali Kraft Cooks with Microwave Pretreatment. U.S. Department of Energy, Washington, D.C.

Office of Industrial Technologies (OIT), 2001b. Proprietary feasibility study of a continuous process for desplacement dewatering - New Process to Dewater Paper Can Reduce Thermal Drying Time and Increase Sheet Bulk. U.S. Department of Energy, Washington, D.C.

Orloff, D., Phelan, P., Asensio, C., 2000. Impulse Drying of South African Furnish, 2000 TAPPI Engineering Conference. TAPPI, Atlanta, Georgia, USA.

Orloff, D.I., Crouse, J.W., 1999. Impulse drying: Status of the pilot-scale research program. TAPPI 82, 143-149. 
Peng, F., Ferritsius, R., Angsas, U., 2005. Method of producing mechanical pulp and the mechanical pulp thus produced. Patent No.: US 2005/0241785 A1.

Pere, J., Ellmen, J., Viikari, L., 2007. Process for preparing mechanical pulp.

Program, S.N.B., 2011. Gasification of black liquor, Popolar scientific summary of the BLG II - program 2007-2010. Available at. http://www.etcpitea.se/pdf/BLG_eng.pdf (accessed March 15, 2012).

Ren, X., 1998. Cleaner production in China's pulp and paper industry. Journal of Cleaner Production 6, 349-355.

Retulainen, E., 2001. Key development phases of condebelt: Long journey from idea to commercial product. Drying Technology 19, 2451-2467.

Retulainen, E., Hamalainen, A., 2000. Three years of condebelt drying at stora enso's pankakoski mill. TAPPI 83, 1-8.

Rio Tinto Minerals (RTM), 2010. Partial Borate Autocausticizing. Available at. http://www.borax.com/autocaust (accessed March 12, 2012).

Sander, A., Bolf, N., Kardu, J.P., 2003. Research on Dynamics and Drying Time in Microwave Paper Drying. Chemical and Biochemical Engineering Quarterly 17, 159-164.

Scott, G.M., Akhtar, M., Lentz, M.J., Kirk, K., Swaney, R., 1998. New technology for papermaking: Commercializing biopulping. TAPPI 81, 153-157.

Strategic energy technologies information system (SETIS), 2010. Bioenergy. European Commission (EC), Available at. http://setis.ec.europa.eu (accessed April 10, 2012).

Strategic energy technologies information system (SETIS), 2011. Technology Innovations for Energy Efficiency and Greenhouse Gas (GHG) Emissions Reduction in the Pulp and Paper Industries in the EU27 up to 2030. SET-Plan Information System (SETIS). European Commission, Brussels, Belgium.

Sholl, D., 2011. Membrane Technologies for Energy Cost Reduction. Georgia Institue of Technology.

Siitonen, S., Ahtila, P., 2010. The influence of operational flexibility on the exploitation of $\mathrm{CO}_{2}$ reduction potential in industrial energy production. Journal of Cleaner Production 18, 867-874.

Silvo, K., Jouttijärvi, T., Melanen, M., 2009. Implications of regulation based on the IPPC directive - A review on the Finnish pulp and paper industry. Journal of Cleaner Production 17, 713-723.

Sinquefield, S.A., Zeng, X., Ball, A.W., 2010. Direct Causticizing for Pressurized Black Liquor Gasification, 2010 TAPPI/PAPTAC International Chemical Recovery Conference. TAPPI, Williamsburg, Virginia, USA.

Soderberg, D., 2006. Potential of new stratification technique, Deliverable D4.2.2, ECOTARGET Publishable Final Activity Report, New and innovative processes for radical changes in the European pulp \& paper industry.

Soderberg, D., 2008. A New Technique for Stratified Forming, 2008 TAPPI PaperCon Conference. TAPPI, Dallas, Texas, USA.

Soderberg, D., 2009. Overview of activities and main results in SP4, Deliverable D4.0.12, ECOTARGET Publishable Final Activity Report, New and innovative processes for radical changes in the European pulp \& paper industry. STFI-Packforsk.

Stawicki, B., Read, B., 2010. The Future of Paper Recycling in Europe: Opportunities and Limitations. The Final Report of COST Action E48 - The Limits of Paper Recycling. The Paper Industry Technical Association (PITA), Bury, Greater Manchester.

Stowell, L., 2007. Membrane Technology for Pre-Evaporation, 2007 Engineering, Pulping \& Environmental Conference. TAPPI.

Swaney, R., Akhtar, M., Horn, E., Lentz, M., Houtman, C., Klungness, J., 2003a. Commercialization of Biopulping: An Energy-saving and Environmentally-friendly Technology for the Paper Industry, 2003 TAPPI Fall Technical Conference. TAPPI, Chicago, Illinois, USA.

Swaney, R., Akhtar, M., Horn, E., Lentz, M., Klungness, J., Sabourin, M., 2003b. Oxalic Acid Pretreatment for Mechanical Pulping Greatly Improves Paper Strength while Maintaining Scattering Power and Reducing Shives and Triglycerides, 2003 TAPPI Fall Technical Conference. TAPPI, Chicago, Illinois, USA. 
Swaney, R.E., 2002. Biopulping: Engineering Scale-Up and Economics, 2002 TAPPI Fall Technical Conference. TAPPI, San Diego, California, USA.

Teledyne, 2012. Teledyne Selected for Emerging Manufacturing Technology Award by DOE. Teledyne Scientific \& Imaging LLC (TS\&I), Available at. http://www.teledyne.com (accessed August 20, 2012).

Thollander, P., Ottosson, M., 2010. Energy management practices in Swedish energy-intensive industries. Journal of Cleaner Production 18, 1125-1133.United Nations Industrial Development Organization (UNIDO), 2010. Global Industrial Energy Efficiency Benchmarking - An Energy Policy Tool.

U.S. Department of Energy (U.S. DOE), 2005. Forest Products Industry of the Future: Quarterly Status Reports.

U.S. Department of Energy (U.S. DOE), 2008. Federal Business Opportunities. Steam Cycle Washer. Available at. https://www.fbo.gov/index?s=opportunity\&mode=form\&id=c751c918fbf764a17e32934ab8dee770\&t $a b=$ core $\&$ tabmode $=$ list $\&=($ accessed March 7, 2012) .

U.S. Environmental Protection Agency (U.S. EPA), 2010. Available and Emerging Technologies for Reducing Greenhouse Gas Emissions from the Pulp and Paper Manufacturing Industry. Research Triangle Park, North Carolina.

Viforr, S., 2008. Enzymatic pre-treatment of wood chips for energy reductions at mechanical pulp production - A review, Deliverable 1.1.11, ECOTARGET 500345.

Wallberg, O., Holmqvist, A., Jönsson, A.-S., 2005. Ultrafiltration of kraft cooking liquors from a continuous cooking process. Desalination 180, 109-118.

Walton, S.L., 2009. Biological Conversion of Hemicellulose Extract into Value-Added Fuels and Chemicals, Chemical Engineering Department. The University of Maine.

Walton, S.L., Hutto, D., Genco, J.M., Walsum, G.P.v., Heiningen, A.R.P.v., 2010. Pre-Extraction of Hemicelluloses from Hardwood Chips Using an Alkaline Wood Pulping Solution Followed by Kraft Pulping of the Extracted Wood Chips. Industrial \& Engineering Chemistry Research 49, 1263812645.

Wang, J., Hou, C.-C., Lin, P.-C., 2013. Two-phase assessment for the environmental impacts from offset lithographic printing on color-box packaging. Journal of Cleaner Production 53, 129-137.

Wang, L., Templer, R., Murphy, R.J., 2012. High-solids loading enzymatic hydrolysis of waste papers for biofuel production. Applied Energy 99, 23-31.

Wang, X.H., Ma, J.H., Jiang, C.L., Brown, W.D., 2007. Treatment of wood chips using enzymes, in: Enzymatic Deinking Technologies, L. (Ed.), U.S.

Wang, Y., Liu, J., Hansson, L., Zhang, K., Wang, R., 2011. Implementing stricter environmental regulation to enhance eco-efficiency and sustainability: a case study of Shandong Province's pulp and paper industry, China. Journal of Cleaner Production 19, 303-310.

Wetterlund, E., 2012. System studies of forest-based biomass gasication, Department of Management and Engineering. Linköping University, Linköping, Sweden.

Worrell, E., 2011. The Next Frontier to Realize Industrial Energy Efficiency, in: Moshfegh, B. (Ed.), World Renewable Energy Congress, Keynote Presentation. Linköping University Electronic Press, Linköping, Sweden.

Worrell, E., Martin, N., Anglani, N., Einstein, D., Khrushch, M., Price, L., 2001. Opportunities to Improve Energy Efficiency and Reduce Greenhouse Gas Emissions in the U.S. Pulp and Paper Industry, Proceedings of Paper Machine Technology, Lanaken, Belgium.

Worrell, E., Price, L., Galitsky, C., 2004. Emerging Energy-Efficient Technologies in Industry: Case Studies of Selected Technologies. Lawrence Berkeley National Laboratory, LBNL-54828, Berkeley, California.

Xu, T., Slaa, J.W., Sathaye, J., 2010. Characterizing Costs, Savings and Benefits of a Selection of Energy Efficient Emerging Technologies in the United States. California Energy Commission. Publication number: BOA-99-205-P. Lawrence Berkeley National Laboratory, Berkeley, California. 
Yoon, S.-H., Cullinan, H., Krishnagopalan, G.A., 2011a. Polysulfide-borohydride modification of southern pine alkaline pulping integrated with hydrothermal pre-extraction of hemicelluloses. TAPPI 94, 9-16.

Yoon, S.-H., Tunc, M.S., Heiningen, A.V., 2011b. Near-neutral pre-extraction of hemicelluloses and subsequent kraft pulping of southern mixed hardwoods. TAPPI 94.

Zafeiris, T., 2010. Global $\mathrm{CO}_{2}$ abatement potential in the pulp and paper industry up to 2030. Utrecht University, the Netherlands.

Zhao, Y., Deng, Y., Zhu, J.Y., 2004. Roles of Surfactants in Flotation Deinking. Progress in Paper Recycling 14, 41-45. 


\section{FIGURE LIST}

Figure 1.World paper and paperboard production

Figure 2. OA pre-treatment in TMP mill

Figure 3. Membrane technology for black liquor pre-evaporation

Figure 4. Diagram of dual pressure reheat recovery boiler

Figure 5. Borate auto-causticizing process

Figure 6. Single-loop fractional deinking

Figure 7. Comparison of conventional and new stratified forming technology

Figure 8. Impulse drying unit in press section

Figure 9. Schematic of Condebelt drying process

Figure 10. Schematic BLG for methanol production

Figure 11. Overview of BIGCC integrated with the pulp and paper mill

Figure 12. Diagram of a hemicellulose extraction process

Figure 13. LignoBoost in chemical pulping plant

Figure 14. Flow diagram of integrated forest biorefinery 


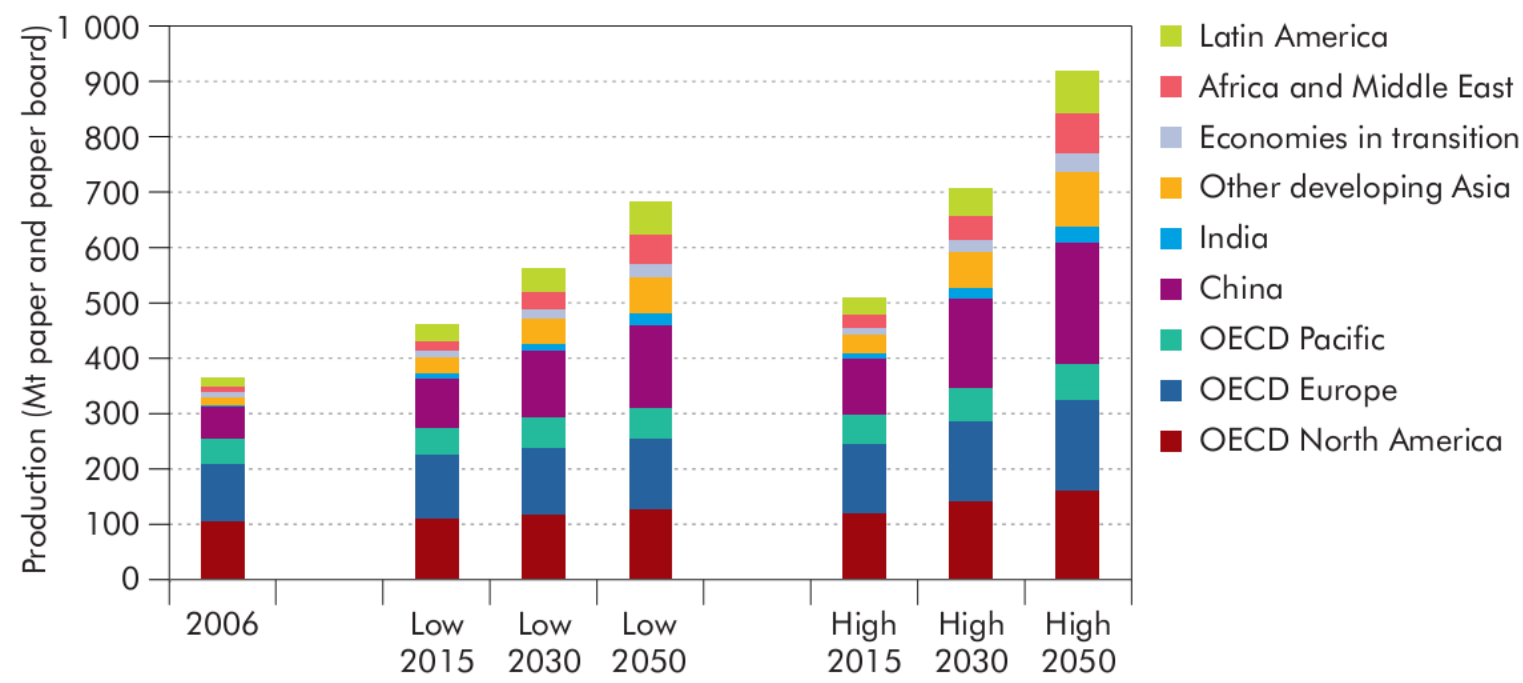

Note: OECD is an acronym for the Organization for Economic Co-operation and Development

Figure 1. World paper and paperboard production (IEA, 2009)

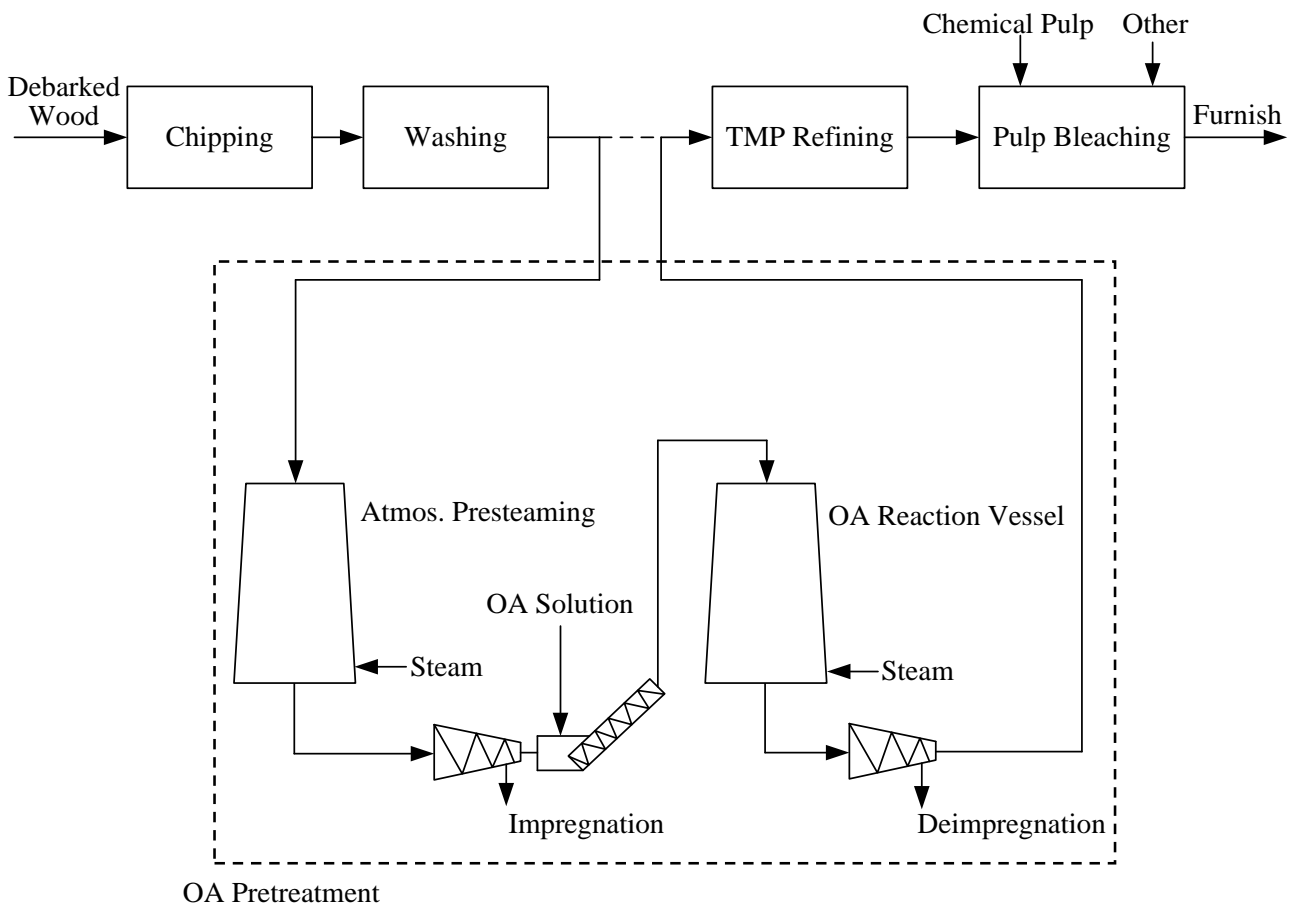

Figure 2. OA pre-treatment in TMP mill (Swaney et al., 2003) 


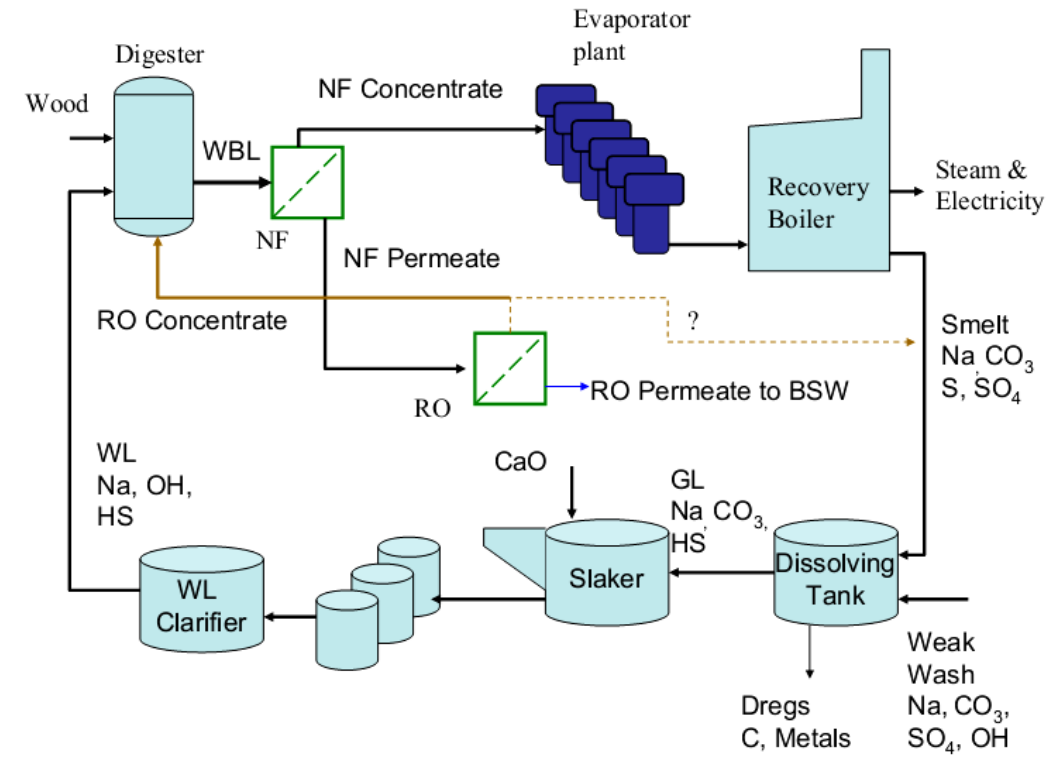

Figure 3. Membrane technology for black liquor pre-evaporation (Sholl, 2011)

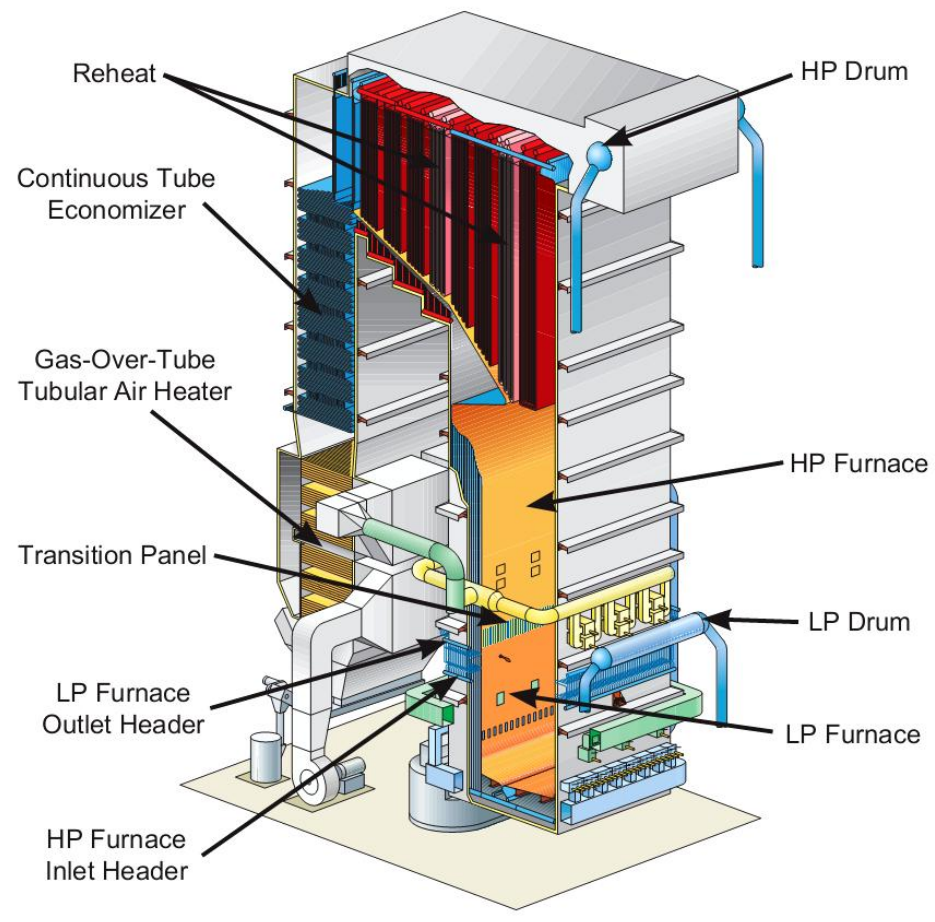

Note: LP means low pressure; HP means high pressure.

Figure 4. Diagram of dual pressure reheat recovery boiler (Hicks et al., 2009) 


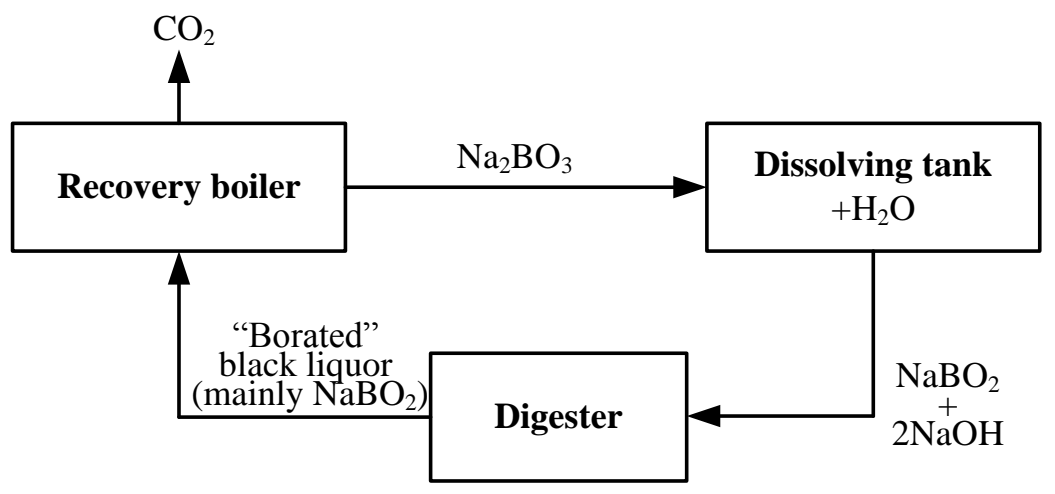

Figure 5. Borate auto-causticizing process (ITP, 2011)
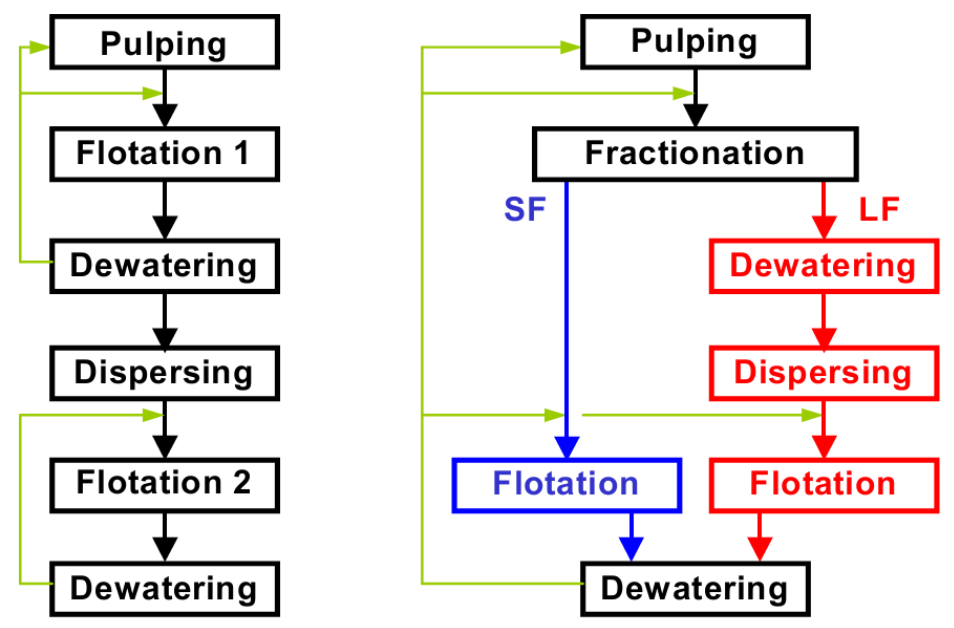

Figure 6. Single-loop fractional deinking (ECOTARGET, 2009)

(Standard 2-loops [left]; new single-loop deinking with recycled paper fractionation [right]) 

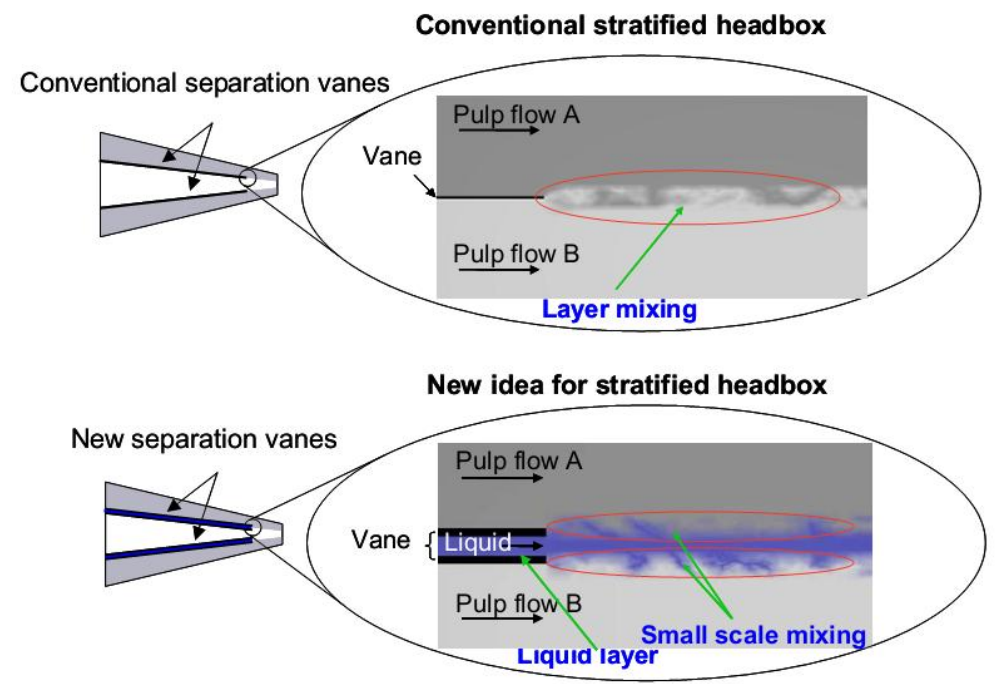

Figure 7. Comparison of conventional and new stratified forming technology (Soderberg, 2006)

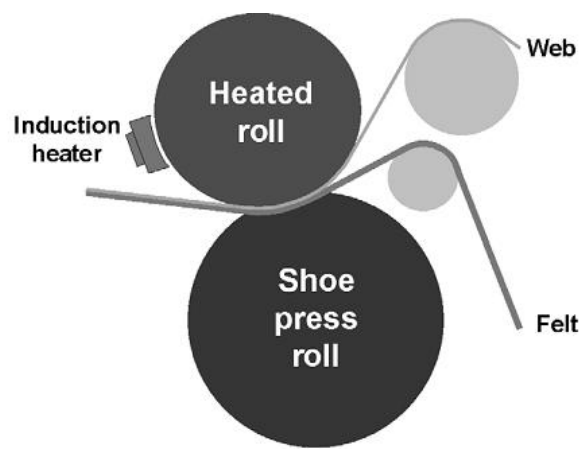

Figure 8. Impulse drying unit in press section (Manninen et al., 2002) 


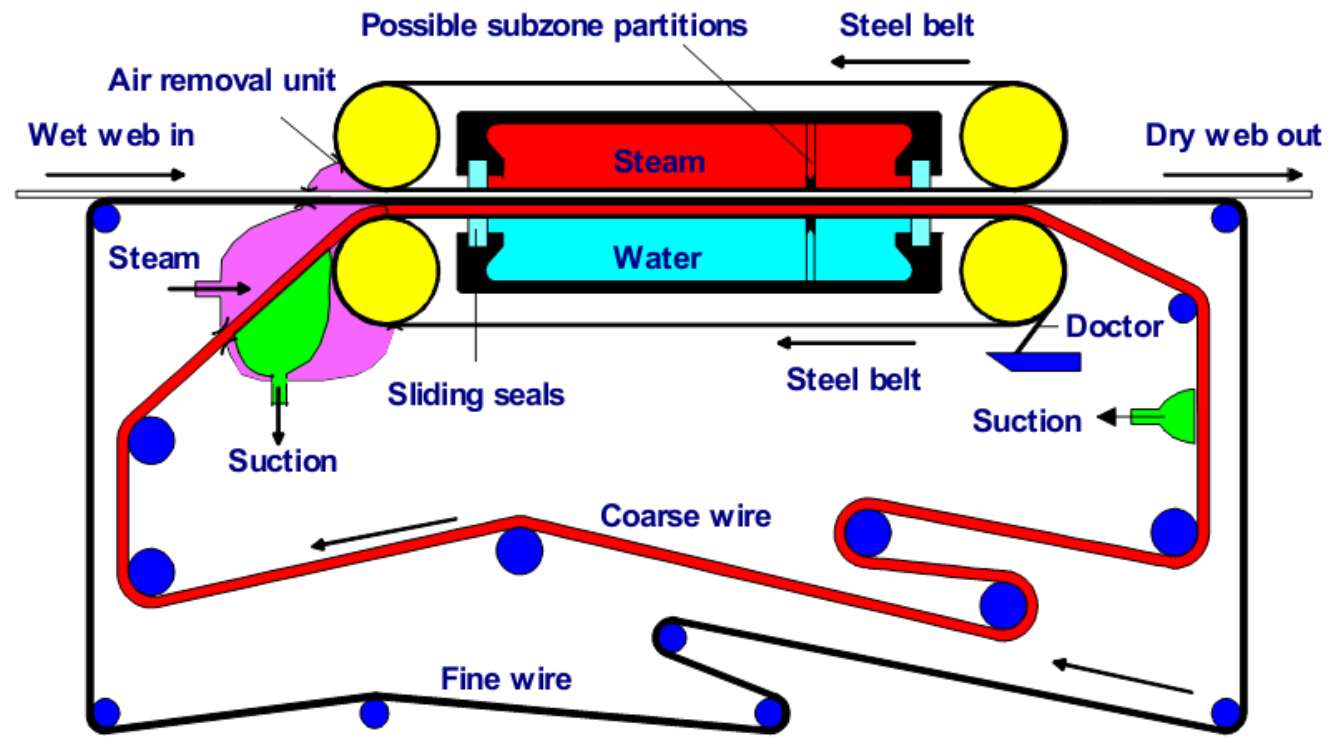

Figure 9. Schematic of Condebelt drying process (Lee et al., 2000)

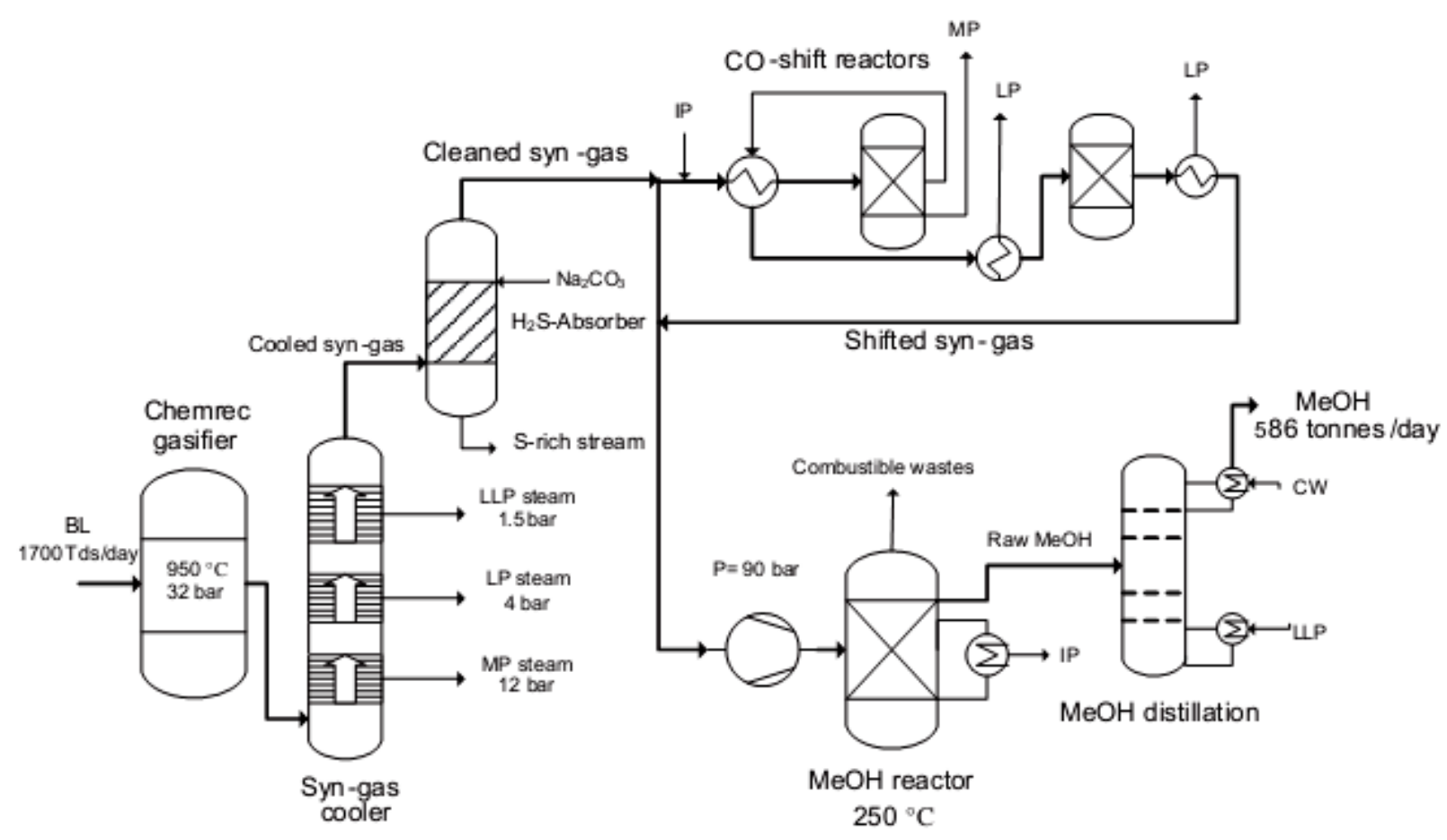

Figure 10. Schematic BLG for methanol production (Naqvi et al., 2012) 


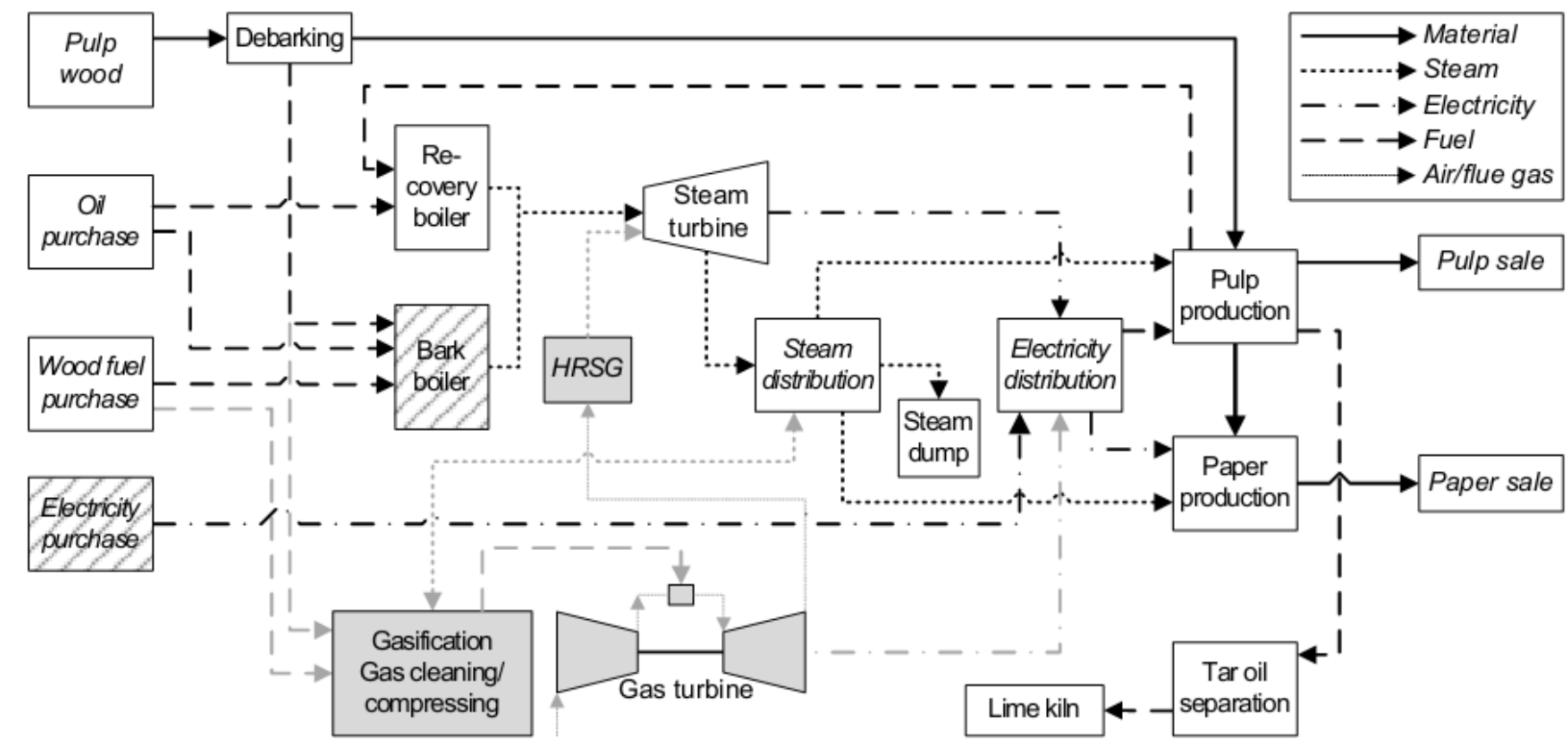

Figure 11. Overview of BIGCC integrated with the pulp and paper mill (Wetterlund, 2012)

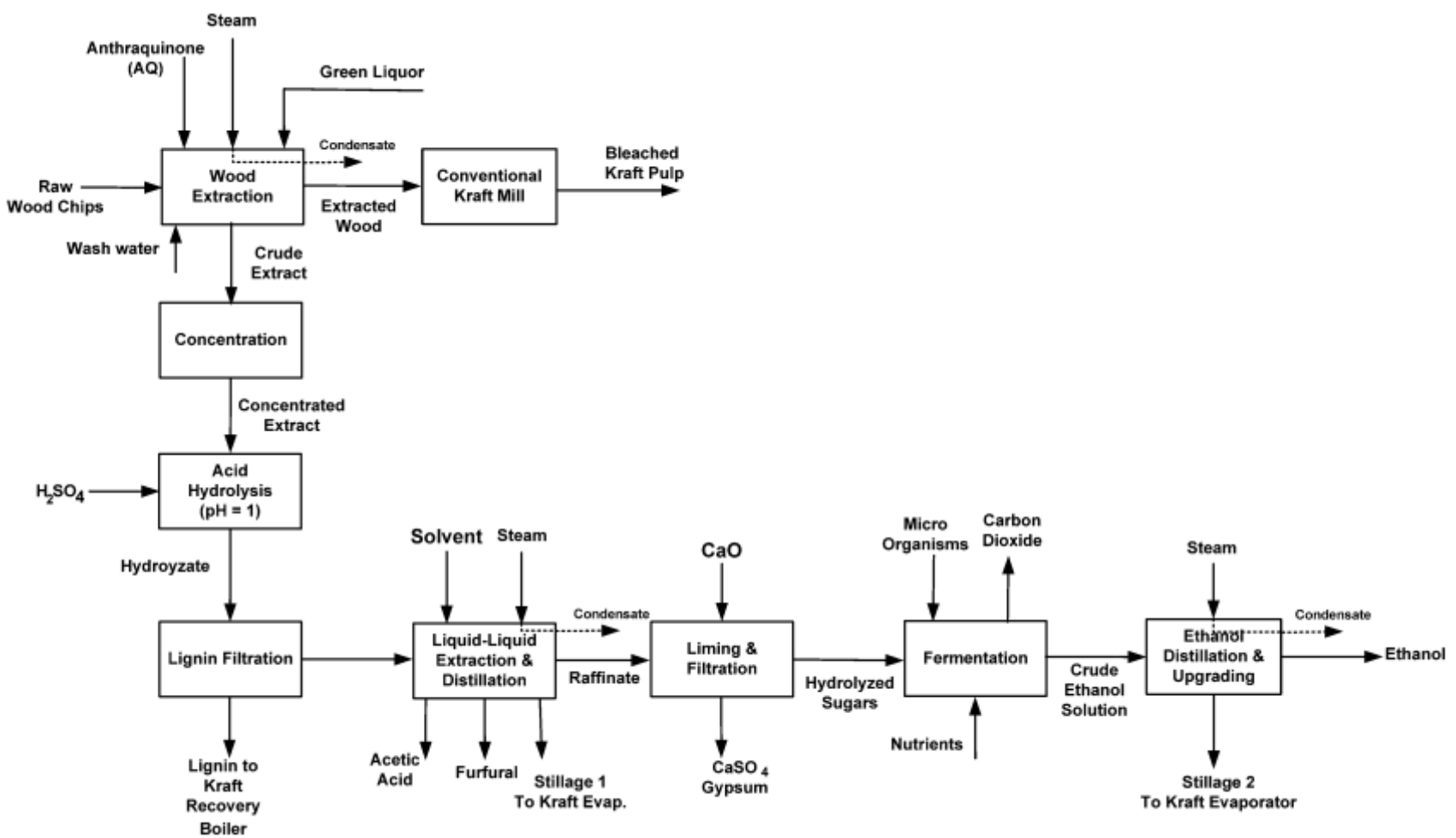

Figure 12. Diagram of a hemicellulose extraction process (Walton et al., 2010) 


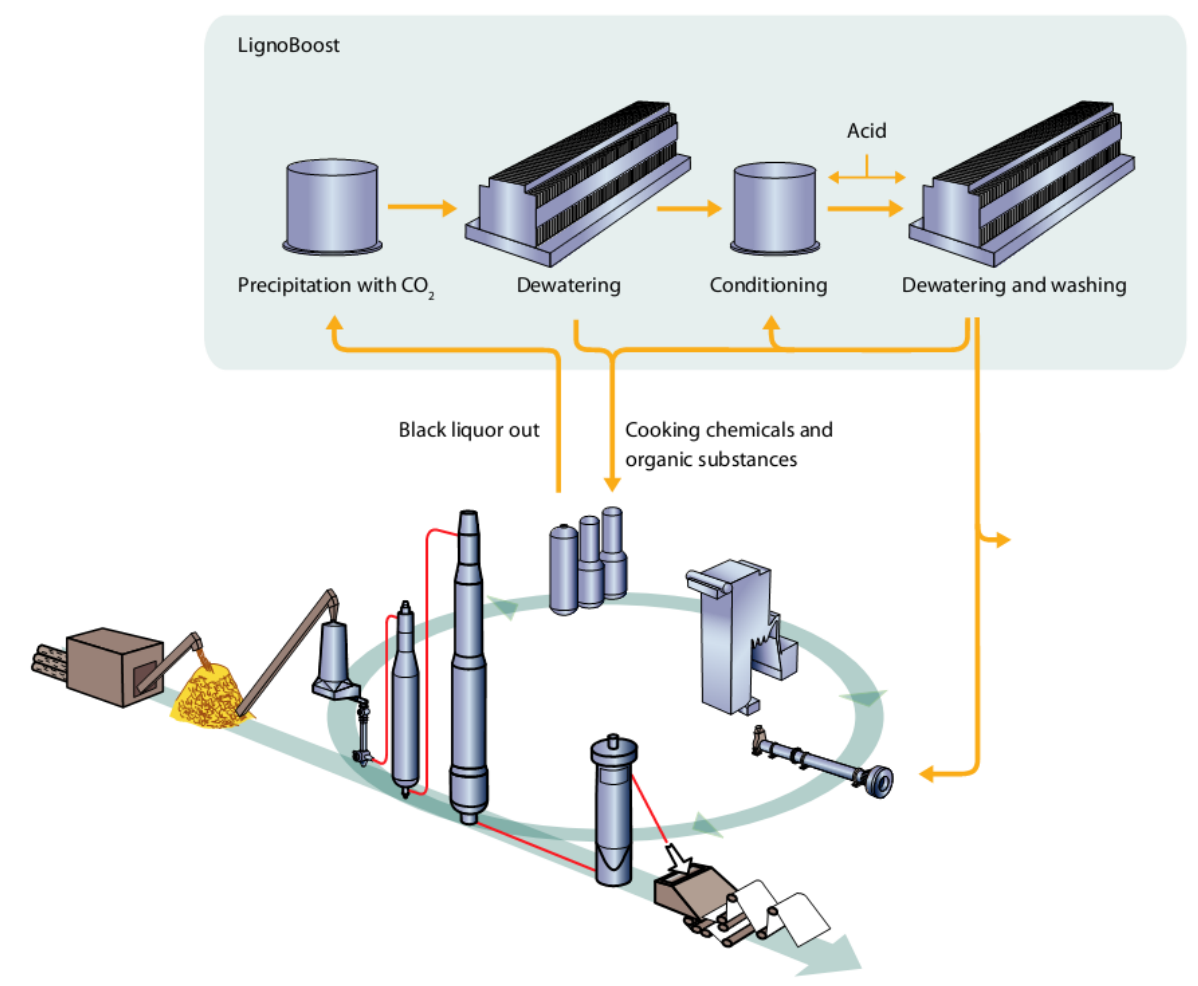

Figure 13. LignoBoost in chemical pulping plant (Metso, 2012)

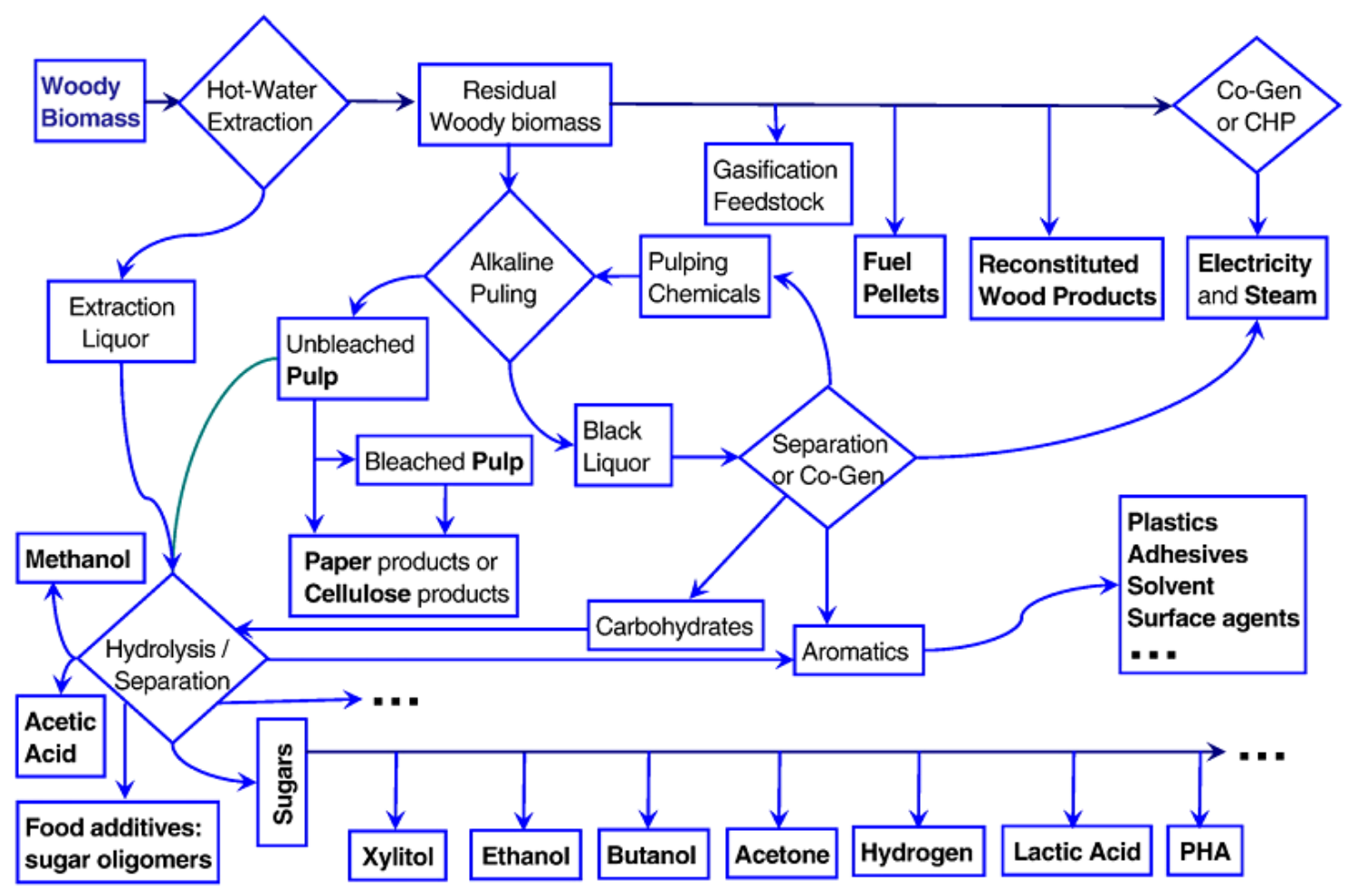

Figure 14. Flow diagram of integrated forest biorefinery (Amidon and Liu, 2009) 


\section{TABLE LIST}

Table 1. Emerging technologies for the pulp and paper industry and a comparison of their benefits and commercialization status

Table 2. An overview of emerging raw material pre-treatment technologies

Table 3. An overview of emerging pulping technologies

Table 4. An overview of emerging papermaking technologies

Table 5. An overview of emerging paper drying technologies

Table 6. An overview of emerging byproduct/biomass utilization technologies

Table 7. The promising biorefinery chains under development 
Table 1. Emerging technologies for the pulp and paper industry and a comparison of their benefits and commercialization status

\begin{tabular}{|c|c|c|c|c|c|c|c|c|c|}
\hline \multirow[b]{2}{*}{ No. } & \multirow[b]{2}{*}{ Category/Technology name } & \multicolumn{2}{|c|}{ (Potential) Benefits } & \multicolumn{5}{|c|}{ Commercial status } & \multirow[b]{2}{*}{$\begin{array}{c}\text { Various } \\
\text { stage }^{*}\end{array}$} \\
\hline & & $\begin{array}{c}\text { Energy } \\
\text { saving }\end{array}$ & $\begin{array}{l}\mathrm{CO}_{2} \\
\text { reduction }\end{array}$ & Research & Development & Pilot & Demo & $\begin{array}{c}\text { Semi- } \\
\text { commercial }\end{array}$ & \\
\hline & Emerging pre-treatment technologies & & & & & & & & \\
\hline 1 & Microwave pre-treatment & $\mathrm{X}$ & $\mathrm{X}$ & & $\mathrm{X}$ & & & & \\
\hline 2 & Chemical pre-treatment with oxalic acid & $\mathrm{X}$ & $\mathrm{X}$ & & & $\mathrm{X}$ & & & \\
\hline 3 & Biological pre-treatment & $\mathrm{X}$ & $X$ & & & & & & $X$ \\
\hline & Emerging pulping technologies & & & & & & & & \\
\hline 4 & Directed green liquor utilization pulping & $\mathrm{X}$ & $\mathrm{X}$ & & & & $X$ & & \\
\hline 5 & Membrane concentration of black liquor & $\mathrm{X}$ & $\mathrm{X}$ & & $X$ & & & & \\
\hline 6 & Dual-pressure reheat recovery boiler & $\mathrm{X}$ & $\mathrm{X}$ & & & $\mathrm{X}$ & & & \\
\hline 7 & Borate auto-causticizing & $\mathrm{X}$ & $\mathrm{X}$ & & & & & & $\mathrm{X}$ \\
\hline 8 & Steam cycle washing & $\mathrm{X}$ & $X$ & & & & $X$ & & \\
\hline 9 & Recycled paper fractionation & $\mathrm{X}$ & $X$ & & & & $X$ & & \\
\hline 10 & Surfactant spray deinking & & $X$ & & & & $X$ & & \\
\hline & Emerging papermaking technologies & & & & & & & & \\
\hline 11 & Aq-vane technology & $\mathrm{X}$ & $\mathrm{X}$ & & $\mathrm{X}$ & & & & \\
\hline 12 & High consistency papermaking & $\mathrm{X}$ & $\mathrm{X}$ & & & $\mathrm{X}$ & & & \\
\hline 13 & Dry sheet forming & $\mathrm{X}$ & $\mathrm{X}$ & & & & & & $\mathrm{X}$ \\
\hline 14 & Displacement pressing & $\mathrm{X}$ & $\mathrm{X}$ & & $\mathrm{X}$ & & & & \\
\hline 15 & Impulse drying in wet pressing process & $\mathrm{X}$ & $X$ & & & & $\mathrm{X}$ & & \\
\hline 16 & New Fibrous fillers & $\mathrm{X}$ & $\mathrm{X}$ & & & $\mathrm{X}$ & & & \\
\hline & Emerging paper drying technologies & & & & & & & & \\
\hline 17 & Gas-fired dryer & $\mathrm{X}$ & $\mathrm{X}$ & & & $\mathrm{X}$ & & & \\
\hline 18 & Boost dryer & $\mathrm{X}$ & $X$ & & & $X$ & & & \\
\hline 19 & Condebelt drying & $\mathrm{X}$ & $X$ & & & & & $X$ & \\
\hline
\end{tabular}


Emerging byproduct/ biomass utilization technologies

21 Black liquor gasification

$X \quad X$

22 Biomass gasification

23 Hemicellulose extraction before chemical pulping

24 LignoBoost

$X \quad X$

25 Other biorefinery concepts

$\begin{array}{ll}X & X \\ X & X\end{array}$

$\mathrm{X}$

$\mathrm{X} \quad \mathrm{X}$

Note: Various stage means the technology are undergoing at least two different stages aforementioned. 
Table 2. An overview of emerging raw material pre-treatment technologies

\begin{tabular}{|c|c|c|c|}
\hline $\begin{array}{l}\text { Technology } \\
\text { Name }\end{array}$ & Energy/Environment/Other Benefits & $\begin{array}{c}\text { Commercial } \\
\text { Status }\end{array}$ & References \\
\hline $\begin{array}{l}\text { Microwave } \\
\text { pre-treatment }\end{array}$ & $\begin{array}{l}\text { - Reduces energy use in chemical pulping and lime kilns } \\
\text { - Reduces energy required for black liquor concentration } \\
\text { - Reduces pulping chemicals and H-factor by } 40 \text { percent } \\
\text { - Improves pulp yield and throughput by } 40 \text { percent in existing Kraft pulp mills } \\
\text { - Increases recovery boiler throughput } \\
\text { - Has capital cost of about } \$ 25 \text { million for a 1,000 air-dry-tonne (Adt) mill with } \\
\text { payback shorter than } 2 \text { years }\end{array}$ & $\begin{array}{l}\text { Development } \\
\text { stage }\end{array}$ & $\begin{array}{l}\text { (Compere, } \\
\text { 2006; DOE, } \\
2005 ; \text { ITP, } \\
2007 \mathrm{a}, \\
2010 \\
2011 \text {; OIT, } \\
\text { 2001a) }\end{array}$ \\
\hline $\begin{array}{l}\text { Chemical } \\
\text { pre-treatment } \\
\text { with oxalic } \\
\text { acid }(\mathrm{OA})\end{array}$ & $\begin{array}{l}\text { - Reduces mechanical pulping energy use by } 20 \text { to } 30 \text { percent compared to energy } \\
\text { - } \text { use without OA pre-treatment } \\
\text { - Reduces resin content by } 30 \text { percent prior to pulping } \\
\text { - Has payback period of } 2 \text { years or shorter } \\
\text { - Improves dewatering efficiency }\end{array}$ & Pilot stage & $\begin{array}{l}\text { (Houtman } \\
\text { and Horn, } \\
2011 ; \text { ITP, } \\
2010 \\
2011 \text {; } \\
\text { Swaney et } \\
\text { al., 2003b) }\end{array}$ \\
\hline $\begin{array}{l}\text { Biological } \\
\text { pre-treatment }\end{array}$ & $\begin{array}{l}\text { a) Fungal pre-treatment } \\
\text { - Saves } 25 \text { to } 40 \text { percent of refining energy compared to conventional refining } \\
\text { without biological pre-treatment } \\
\text { - Improves paper quality, e.g., enhanced paper strength and reduced pitch content } \\
\text { - Extends refiner lifetime } \\
\text { b) Enzymatic pre-treatment } \\
\text { - Pectinase pre-treatment of wood chips - saves up to } 20 \text { percent of refining } \\
\text { - } \text { process energy } \\
\text { - } \text { pylanase pre-treatment of hardwood chips - saves up to } 26 \text { percent of refining } \\
\text { - Using cellulase and cellulase mixture pre-treatment of softwood chips - } \\
\text { - } \text { - Enssibly reduces refining energy use by up to } 20 \text { percent } \\
25 \text { percent re-treatment generally - possibly reduces refining energy by } 10 \text { to } \\
\text { enzymatic pre-treatment }\end{array}$ & $\begin{array}{l}\text { a) Semi- } \\
\text { commercial } \\
\text { stage for } \\
\text { fungal pre- } \\
\text { treatment; } \\
\text { b) Pilot state } \\
\text { for enzymatic } \\
\text { pre-treatment }\end{array}$ & $\begin{array}{l}\text { (ECOTARG } \\
\text { ET, 2009; } \\
\text { Girard et al., } \\
\text { 2006; Peng } \\
\text { et al., 2005; } \\
\text { Pere et al., } \\
\text { 2007; Scott } \\
\text { et al., 1998) }\end{array}$ \\
\hline
\end{tabular}


Table 3. An overview of emerging pulping technologies

\begin{tabular}{|c|c|c|c|}
\hline $\begin{array}{l}\text { Technology } \\
\text { Name }\end{array}$ & Energy/Environment/Other Benefits/Costs & $\begin{array}{c}\text { Commercial } \\
\text { Status }\end{array}$ & References \\
\hline $\begin{array}{l}\text { Directed } \\
\text { green liquor } \\
\text { utilization } \\
\text { pulping }\end{array}$ & $\begin{array}{l}\text { - Reduces energy consumption by up to } 25 \text { percent } \\
\text { - Reduces effective alkali consumption in digesters by as much as } 50 \\
\text { percent } \\
\text { - Reduces lime kiln load by up to } 30 \text { percent, which in turn reduces lime } \\
\text { kiln fuel consumption } \\
\text { - Reduces H-factor by } 30 \text { percent at similar Kappa number } \\
\text { - Increases pulp yield } 1 \text { to } 3 \text { percent } \\
\text { - Increases pulp strength (10-percent gain in tear strength) as well as } \\
\text { bleachability }\end{array}$ & $\begin{array}{l}\text { Demonstration } \\
\text { stage }\end{array}$ & $\begin{array}{l}\text { (ITP, 2011a; } \\
\text { Lucia, 2005) }\end{array}$ \\
\hline $\begin{array}{l}\text { Membrane } \\
\text { concentration } \\
\text { of black } \\
\text { liquor }\end{array}$ & $\begin{array}{l}\text { - Reduces energy cost for black liquor evaporation } \\
\text { - Reduces evaporation volume } \\
\text { - } \text { Decreases inorganic content to evaporators resulting in less fouling } \\
\text { - } \text { Active alkali concentrated in permeate for improved make up liquor } \\
\text { - } \text { Lower boiling point rise with ultra-filtration concentration } \\
\text { Elimate evaporator or recovery boiler bottlenecks }\end{array}$ & $\begin{array}{l}\text { Development } \\
\text { stage }\end{array}$ & $\begin{array}{l}\text { (Adnan et al., } \\
\text { 2010; } \\
\text { Holmqvist et al., } \\
\text { 2005; Sholl, } \\
\text { 2011; Stowell, } \\
\text { 2007) }\end{array}$ \\
\hline $\begin{array}{l}\text { Dual-pressure } \\
\text { reheat } \\
\text { recovery } \\
\text { boiler }\end{array}$ & $\begin{array}{l}\text { - Improves steam cycle efficiency } \\
\text { - Increases electricity generation for the same fuel input } \\
\text { - Takes advantage of existing plant infrastructure } \\
\text { - Lower GHG emissions due to higher efficiency and reduced fossil fuel } \\
\text { use } \\
\text { - Short return on investment }\end{array}$ & Pilot stage & $\begin{array}{l}\text { (B\&W, 2009; } \\
\text { Hicks, 2011; } \\
\text { Hicks et al., } \\
\text { 2009; Monacelli } \\
\text { et al., 2008) }\end{array}$ \\
\hline $\begin{array}{l}\text { Borate auto- } \\
\text { causticizing }\end{array}$ & $\begin{array}{l}\text { - Increases energy efficiency in chemical recovery process } \\
\text { - Reduces lime demand, which reduces fossil fuel use in traditional lime } \\
\text { kiln } \\
\text { - Decreases fresh lime usage and lime mud disposal costs } \\
\text { - Reduces } \mathrm{CO}_{2} \text { emissions from fuel burning and from calcining process } \\
\text { in lime kiln } \\
\text { - Increases causticizing capacity and pulp production without major } \\
\text { investments } \\
\text { - Decreases lime kiln O\&M costs }\end{array}$ & $\begin{array}{l}\text { Development } \\
\text { for full auto- } \\
\text { causticizing; } \\
\text { Semi- } \\
\text { commercial for } \\
\text { partial auto- } \\
\text { causticizing }\end{array}$ & $\begin{array}{l}\text { (Bjork et al., } \\
\text { 2005; Hunter et } \\
\text { al., 2001; ITP, } \\
\text { 2006c, 2011b; } \\
\text { Kochesfahani } \\
\text { and Bair, 2002; } \\
\text { RTM, 2010) }\end{array}$ \\
\hline $\begin{array}{l}\text { Steam cycle } \\
\text { washing }\end{array}$ & $\begin{array}{l}\text { - Reduces fuel/steam consumption } 40 \text { percent overall } \\
\text { - Reduces evaporative load } 50 \text { percent } \\
\text { - Reduces plant effluent and freshwater usage } 45 \text { percent } \\
\text { - Increases fiber yield } 1 \text { to } 2 \text { percent } \\
\text { - Reduces bleaching chemical consumption } \\
\text { - Can reduce operational costs by } \$ 40 \text { to } \$ 60 / \text { Adt pulp }\end{array}$ & $\begin{array}{l}\text { Demonstration } \\
\text { stage }\end{array}$ & $\begin{array}{l}\text { (DOE, 2008; } \\
\text { Muehlethaler et } \\
\text { al., 2008) }\end{array}$ \\
\hline $\begin{array}{l}\text { Recycled } \\
\text { paper } \\
\text { fractionation }\end{array}$ & $\begin{array}{l}\text { - } \text { Decreases energy consumption } \\
\text { - Improves efficiency of ink detachment } \\
\text { - Reduces redeposition of ink on fibers } \\
\text { - Reduces virgin fiber consumption } \\
\text { - Increases DIP production } \\
\text { Improves pulp quality }\end{array}$ & $\begin{array}{l}\text { Demonstration } \\
\text { stage }\end{array}$ & $\begin{array}{l}\text { (ECOTARGET, } \\
2009 ; \\
\text { Kemppainen et } \\
\text { al., 2011; } \\
\text { Korkko et al., } \\
\text { 2011) }\end{array}$ \\
\hline $\begin{array}{l}\text { Surfactant } \\
\text { spray } \\
\text { deinking }\end{array}$ & $\begin{array}{l}\text { - Reduces fiber loss up to } 50 \text { percent } \\
\text { - Increases DIP yield (IPST demonstrated a } 3.5 \text {-percent yield increase) } \\
\text { - Improves deinking efficiency } \\
\text { - Reduces water and deinking chemical use ( } 380 \text { liters per minute of } \\
\text { - } \text { Reduces savings and } 10 \text { percent of chemical savings were realized in IPST) } \\
\text { - Improves paper quality } \\
\text { - Requires low capital expenditure and minimal equipment modification }\end{array}$ & $\begin{array}{l}\text { Demonstration } \\
\text { stage }\end{array}$ & $\begin{array}{l}\text { (Delozier et al., } \\
\text { 2005; Deng and } \\
\text { Zhu, 2004; ITP, } \\
\text { 2007b) }\end{array}$ \\
\hline
\end{tabular}


Table 4. An overview of emerging papermaking technologies

\begin{tabular}{|c|c|c|c|}
\hline $\begin{array}{l}\text { Technology } \\
\text { Name }\end{array}$ & Energy/Environment/Other Benefits/Costs & $\begin{array}{l}\text { Commercial } \\
\text { Status }\end{array}$ & References \\
\hline $\begin{array}{l}\text { Aq-vane } \\
\text { technology }\end{array}$ & $\begin{array}{l}\text { - Reduces fibrous raw material use } \\
\text { - Reduces energy consumption due to less fiber raw materials usage } \\
\text { - Improves paper properties with higher layer purity } \\
\text { - Improves web surface roughness and bending stiffness } \\
\text { - Reduces operation costs }\end{array}$ & $\begin{array}{l}\text { Development } \\
\text { stage }\end{array}$ & $\begin{array}{l}\text { (ECOTARG } \\
\text { ET, 2009; } \\
\text { Soderberg, } \\
\text { 2006, 2008, } \\
\text { 2009) }\end{array}$ \\
\hline $\begin{array}{l}\text { High } \\
\text { consistency } \\
\text { papermaking }\end{array}$ & $\begin{array}{l}\text { - Reduces energy use in stock preparation, vacuum system, and dewatering } \\
\text { - Electricity savings are estimated at } 8 \% \text { percent } \\
\text { - Reduces water consumption in papermaking } \\
\text { - Saving fiber use by } 5-8 \text { percent } \\
\text { - Reduces chemical additives } \\
\text { - Simplifies wet end process of papermaking } \\
\text { - Improves product quality } \\
\text { - Reduction of } 10-15 \text { percent in capital costs for the wet end of the machine } \\
\text { - High consistency formers are expected to cost } \$ 70 / t \text { paper with an } \\
\text { additional maintenance cost of } \$ 0.72 / t \text { paper }\end{array}$ & Pilot stage & $\begin{array}{l}\text { (Cichoracki } \\
\text { et al., 2001; } \\
\text { EC, 2012; } \\
\text { Martin et al., } \\
\text { 2000a; } \\
\text { Martin et al., } \\
\text { 2000b) }\end{array}$ \\
\hline $\begin{array}{l}\text { Dry sheet } \\
\text { forming }\end{array}$ & $\begin{array}{l}\text { - Reduces drying energy consumption by } 50 \text { percent, reportedly } \\
\text { approximately } 5 \mathrm{GJ} / \mathrm{t} \text { paper of fuel saved } \\
\text { - Increases electricity use of } 150 \text { to } 250 \mathrm{kWh} / \mathrm{t} \text { paper } \\
\text { - Eliminates wastewater effluent and treatment } \\
\text { - Has investment costs } 30 \text { to } 50 \text { percent of those for a conventional non- } \\
\text { integrated paper mill } \\
\text { - Has lower O\&M costs compared to conventional technology } \\
\text { - Produces softer paper products }\end{array}$ & $\begin{array}{l}\text { Development for } \\
\text { producing } \\
\text { standard paper } \\
\text { grades ; } \\
\text { Semi-commercial } \\
\text { for production of } \\
\text { specialty products }\end{array}$ & $\begin{array}{l}\text { (de Beer et } \\
\text { al., 1998; } \\
\text { Jiang, 1997; } \\
\text { Martin et al., } \\
\text { 2000b; Xu } \\
\text { et al., 2010) }\end{array}$ \\
\hline $\begin{array}{l}\text { Displacement } \\
\text { pressing }\end{array}$ & $\begin{array}{l}\text { - Reduces drying energy consumption } \\
\text { - Increases web solids content before dryer } \\
\text { - Improves paper strength properties } \\
\text { - Reduces paper breaks } \\
\text { - Reduces raw material costs }\end{array}$ & $\begin{array}{l}\text { Development } \\
\text { stage }\end{array}$ & $\begin{array}{l}\text { (Agenda202 } \\
0,2010 ; \\
\text { Beck, 2006; } \\
\text { Chudnovsky } \\
\text { et al., 2004; } \\
\text { Ghosh, } \\
\text { 2009; OIT, } \\
\text { 2001b) }\end{array}$ \\
\hline $\begin{array}{l}\text { Impulse } \\
\text { drying in wet } \\
\text { pressing } \\
\text { process }\end{array}$ & $\begin{array}{l}\text { - Reduces water evaporation in dryer section by } 175 \text { to } 350 \mathrm{~kg} \text { water/t paper } \\
\text { - Reduces steam consumption for drying in the range of } 0.44 \text { to } 0.9 \mathrm{GJ} / \mathrm{t} \\
\text { paper, which is a } 10 \text { - to } 25 \text {-percent reduction in steam consumption } \\
\text { - Increases drying rates by } 50 \text { to } 500 \text { times } \\
\text { - Improves productivity by } 20 \text { percent } \\
\text { - Improves paper properties, such as web smoothness, strength, and stiffness } \\
\text { - Decreases dryer section length or paper machine length } \\
\text { - Reduces capital investment and O\&M costs }\end{array}$ & $\begin{array}{l}\text { Demonstration } \\
\text { stage }\end{array}$ & $\begin{array}{l}\text { (de Beer et } \\
\text { al., 1998; } \\
\text { EC, 2001; } \\
\text { Orloff et al., } \\
\text { 2000; Orloff } \\
\text { and Crouse, } \\
1999 ; \text { Xu et } \\
\text { al., 2010) }\end{array}$ \\
\hline $\begin{array}{l}\text { New fibrous } \\
\text { fillers }\end{array}$ & $\begin{array}{l}\text { - Reduces energy use by } 25 \text { percent } \\
\text { - Replaces expensive fillers, such as } \mathrm{TiO} 2 \text { and silica } \\
\text { - Increases solid content of paper web } \\
\text { - Improves retention/Increases water drainage rate } \\
\text { - Improves paper optical properties (brightness, opacity, printing quality) } \\
\text { - Reduces BOD, COD, and turbidity in mill process water } \\
\text { - Creates additional revenue in new products }\end{array}$ & Pilot stage & $\begin{array}{l}\text { (ITP, 2006b, } \\
2010 ; \\
\text { Mathur, } \\
\text { 2006) }\end{array}$ \\
\hline
\end{tabular}


Table 5. An overview of emerging paper drying technologies

\begin{tabular}{|c|c|c|c|}
\hline $\begin{array}{c}\text { Technology } \\
\text { Name }\end{array}$ & Energy/Environment/Other Benefits/Costs & $\begin{array}{c}\text { Commercial } \\
\text { Status }\end{array}$ & References \\
\hline Gas-fired dryer & $\begin{array}{l}\text { - Reduces drying energy consumption by } 10 \text { to } 20 \text { percent } \\
\text { - Increases production by up to } 20 \text { percent } \\
\text { - Improves drying rate } \\
\text { - Achieves higher surface temperatures } \\
\text { - Has a short installation time } \\
\text { - Has lower initial capital investment }\end{array}$ & Pilot stage & $\begin{array}{l}\text { (Chudnovsky, } \\
2011 ; \\
\text { Chudnovsky } \\
\text { and } \\
\text { J.DiGiacomo, } \\
\text { 2006; } \\
\text { Chudnovsky } \\
\text { et al., 2004; } \\
\text { ITP, 2006c, d) }\end{array}$ \\
\hline Boost dryer & $\begin{array}{l}\text { - Reduces specific energy consumption } \\
\text { - Increases drying efficiency, and increases drying capacity by } \\
\text { approximately } 12 \text { percent } \\
\text { - Reduces drying time } \\
\text { - Reduces space needed for dryer section } \\
\text { - Improves paper quality (e.g., breaking strength, bending stiffness, } \\
\text { smoothness) }\end{array}$ & Pilot stage & $\begin{array}{l}\text { (Haase, 2005; } \\
\text { Karner and } \\
\text { Herzog, 2008) }\end{array}$ \\
\hline $\begin{array}{l}\text { Condebelt } \\
\text { drying }\end{array}$ & $\begin{array}{l}\text { - Reduces steam consumption by } 10 \text { to } 20 \text { percent } \\
\text { - Saves an estimated } 1.6 \mathrm{GJ} / \mathrm{t} \text { paper in steam, } 20 \mathrm{kWh} / \mathrm{t} \text { paper in electricity } \\
\text { - Increases drying rates by } 5 \text { to } 15 \text { times } \\
\text { - Increases machine productivity } \\
\text { - Improves paper properties, and significantly improves paper strength (by } \\
\text { - } 20 \text { to } 60 \text { percent) } \\
\text { Does not significantly change O\&M costs }\end{array}$ & $\begin{array}{l}\text { Semi- } \\
\text { commercial } \\
\text { stage }\end{array}$ & $\begin{array}{l}\text { (de Beer et al., } \\
\text { 1998; EC, } \\
\text { 2001; Martin } \\
\text { et al., 2000a) }\end{array}$ \\
\hline $\begin{array}{l}\text { Microwave } \\
\text { drying }\end{array}$ & $\begin{array}{l}\text { - Reduces overall energy consumption by } 12 \text { percent } \\
\text { - Increases dryer temperature and drying efficiency } \\
\text { - Increases paper machine speed by } 30 \text { percent } \\
\text { - Has lower overall investment costs for new machines } \\
\text { - Reduces maintenance costs } \\
\text { - Has payback period is shorter than } 2.5 \text { years (for high basis weight paper } \\
\text { - } \text { machine, payback is only } 0.5 \text { to } 1 \text { year) } \\
\text { Eliminates over drying }\end{array}$ & $\begin{array}{l}\text { Development } \\
\text { stage }\end{array}$ & $\begin{array}{l}\text { (Ahrens, } \\
\text { 2003; ITP, } \\
\text { 2006a; Sander } \\
\text { et al., 2003) }\end{array}$ \\
\hline
\end{tabular}


Table 6. An overview of emerging byproduct/biomass utilization technologies

\begin{tabular}{|c|c|c|c|}
\hline $\begin{array}{c}\text { Technology } \\
\text { Name }\end{array}$ & Energy/Environment/Other Benefits/Costs & $\begin{array}{c}\text { Commercial } \\
\text { Status }\end{array}$ & References \\
\hline $\begin{array}{l}\text { Black liquor } \\
\text { gasification }\end{array}$ & $\begin{array}{l}\text { - Increases pulping process energy recovery by } 10 \text { percent } \\
\text { - Increases pulp mill power production by two to three times } \\
\text { - Decreases missions and carbon footprint by up to } 95 \text { percent } \\
\text { - BLGCC system has investment } 60 \text { to } 90 \text { percent higher than for } \\
\text { - } \text { Increases pulp yield by about } 5 \text { to } 7 \text { percent }\end{array}$ & $\begin{array}{l}\text { Demonstration } \\
\text { stage for } \\
\text { atmospheric low- } \\
\text { temperature BLG; } \\
\text { Pilot stage for } \\
\text { pressurized high- } \\
\text { temperature BLG }\end{array}$ & $\begin{array}{l}\text { (Chemrec, } \\
\text { 2012; } \\
\text { Cheremisinoff } \\
\text { and Rosenfeld, } \\
\text { 2010; Gebart, } \\
\text { 2006; IEA, } \\
\text { 2009; Program, } \\
\text { 2011; Worrell } \\
\text { et al., 2004) }\end{array}$ \\
\hline $\begin{array}{l}\text { Biomass } \\
\text { gasification }\end{array}$ & $\begin{array}{l}\text { - Reduces fossil fuel use and } \mathrm{CO}_{2} \text { emissions for pulp and paper mills } \\
\text { - Lowers nitrogen oxide (NOx) emissions } 30 \text { to } 40 \text { percent } \\
\text { - Reduces waste solids disposal costs } \\
\text { - Provides significant added value to the pulp and paper industry } \\
\text { - Can provide feedstock for chemical industry } \\
\text { - Can provide biofuel for transport sector }\end{array}$ & $\begin{array}{l}\text { Different } \\
\text { commercial status } \\
\text { for different } \\
\text { biomass } \\
\text { gasification } \\
\text { concepts, most of } \\
\text { which are under } \\
\text { pilot and } \\
\text { demonstration } \\
\text { stage currently. }\end{array}$ & $\begin{array}{l}\text { (Ahl, 2012; } \\
\text { Bain et al., } \\
\text { 2003; Ciferno } \\
\text { and Marano, } \\
\text { 2002; EBTP, } \\
\text { 2012a; IEA, } \\
\text { 2009; Nexterra, } \\
\text { 2012; } \\
\text { Wetterlund, } \\
\text { 2012) }\end{array}$ \\
\hline $\begin{array}{l}\text { Hemicellulose } \\
\text { extraction } \\
\text { before } \\
\text { chemical } \\
\text { pulping }\end{array}$ & $\begin{array}{l}\text { - Reduces kraft cooking time } \\
\text { - Enhances cooking liquor impregnation } \\
\text { - Decreases alkali consumption } \\
\text { - Improves the energy efficiency of kraft pulp mill } \\
\text { - Improves the profitability of kraft mill } \\
\text { - Increases production capacity for pulp mills that are limited by the } \\
\text { - Necovery boiler } \\
\text { - } \text { in tear }\end{array}$ & Pilot stage & $\begin{array}{l}\text { (Amidon and } \\
\text { Liu, 2009; } \\
\text { Bajpai, 2012; } \\
\text { Huang et al., } \\
\text { 2010; Jun et } \\
\text { al., 2012; Mao } \\
\text { et al., 2008; } \\
\text { Walton, 2009; } \\
\text { Walton et al., } \\
\text { 2010; Yoon et } \\
\text { al., 2011a) }\end{array}$ \\
\hline LignoBoost & $\begin{array}{l}\text { - Replaces fossil fuel in lime kilns and recovery boilers } \\
\text { - Gives pulp mill new potential to increase production and reduce costs } \\
\text { - Generates additional income for pulp and paper mills } \\
\text { - Supplies renewable raw materials for other industrial sectors }\end{array}$ & Pilot stage & $\begin{array}{l}\text { (Gosselink et } \\
\text { al., 2004; IEA, } \\
\text { 2009; } \\
\text { Innventia, } \\
\text { 2012; Metso, } \\
\text { 2012; SETIS, } \\
2011)\end{array}$ \\
\hline $\begin{array}{l}\text { Other } \\
\text { biorefinery } \\
\text { concepts }\end{array}$ & $\begin{array}{l}\text { - Improves energy efficiency for the pulp and paper industry } \\
\text { - Reduces raw materials use in other industrial sectors } \\
\text { - } \text { Provides significant added value to the pulp and paper industry } \\
\text { - Reduces raw materials use in other industrial sectors }\end{array}$ & $\begin{array}{l}\text { Different stages } \\
\text { for different } \\
\text { biorefining } \\
\text { process }\end{array}$ & $\begin{array}{l}\text { (Amidon and } \\
\text { Liu, 2009; } \\
\text { CEPI, 2009; } \\
\text { Cherubini, } \\
\text { 2010; EBTP, } \\
\text { 2011, 2012a, b; } \\
\text { FitzPatrick et } \\
\text { al., 2010; } \\
\text { Fornell and } \\
\text { Berntsson, } \\
\text { 2012; } \\
\text { Hellsmark, } \\
\text { 2011; Heyne } \\
\text { and Harvey, } \\
\text { 2012; Huang et } \\
\text { al., 2010; IEA, } \\
\text { 2009, 2010b; } \\
\text { Jönsson et al., } \\
\text { 2011; Mäkinen } \\
\text { et al., 2011; } \\
\text { Mora et al., } \\
\text { 2011; } \\
\text { Moshkelani et }\end{array}$ \\
\hline
\end{tabular}




\begin{tabular}{|c|l|l|l|}
\hline $\begin{array}{c}\text { Technology } \\
\text { Name }\end{array}$ & \multicolumn{1}{|c|}{ Energy/Environment/Other Benefits/Costs } & \multicolumn{1}{c|}{$\begin{array}{c}\text { Commercial } \\
\text { Status }\end{array}$} & \multicolumn{1}{|c|}{ References } \\
\hline & & & al., 2012; \\
& & & Naqvi et al., \\
& & & 2012a; SETIS, \\
& & & Stawicki and \\
& & & Read, 2010; \\
& & & Wang et al., \\
& & & 2012) \\
\hline
\end{tabular}


Table 7. The most promising biorefinery chains under development (EBTP, 2011)

\begin{tabular}{|c|c|c|c|c|}
\hline & Biorefinery chain name & Technology challenges & $\begin{array}{l}\text { Development } \\
\text { status }\end{array}$ & $\begin{array}{l}\text { Preliminary costs } \\
\text { estimates } \\
\text { (demonstration } \\
\text { plant/ first } \\
\text { commercial plant) } \\
\text { (Million Euros)* }\end{array}$ \\
\hline \multicolumn{5}{|c|}{ Thermochemical paths } \\
\hline 1 & $\begin{array}{l}\text { Synthetic liquid fuels and/or hydrocarbons } \\
\text { (e.g. gasoline, naphtha, kerosene or diesel } \\
\text { fuel) and blending components through } \\
\text { gasification }\end{array}$ & $\begin{array}{l}\text { Feeders, gas cleaning, } \\
\text { catalysts }\end{array}$ & $\begin{array}{l}\text { Demonstration } \\
\text { stage }\end{array}$ & $\begin{array}{l}40-100 / \\
400-1000\end{array}$ \\
\hline 2 & $\begin{array}{l}\text { Bio-methane and other bio-synthetic gaseous } \\
\text { fuels through gasification }\end{array}$ & $\begin{array}{l}\text { Feeders, gas cleaning, } \\
\text { catalysts }\end{array}$ & Pilot stage & $\begin{array}{l}20-40 / \\
200-300\end{array}$ \\
\hline 3 & $\begin{array}{l}\text { High efficiency heat \& power generation } \\
\text { through thermochemical conversion }\end{array}$ & $\begin{array}{l}\text { Bio-feedstock compatible } \\
\text { materials, high share of } \\
\text { power generation }\end{array}$ & $\begin{array}{l}\text { Demonstration } \\
\text { stage }\end{array}$ & $\begin{array}{l}20-40 / \\
150-250\end{array}$ \\
\hline 4 & $\begin{array}{l}\text { Intermediate bioenergy carriers through } \\
\text { techniques such as pyrolysis and torrefaction }\end{array}$ & $\begin{array}{l}\text { Handling/stability of bio-oil, } \\
\text { materials, specifications of } \\
\text { intermediates }\end{array}$ & $\begin{array}{l}\text { Demonstration } \\
\text { stage }\end{array}$ & $\begin{array}{l}20-40 / \\
50-100\end{array}$ \\
\hline \multicolumn{5}{|c|}{ Biochemical paths } \\
\hline 5 & $\begin{array}{l}\text { Ethanol and higher alcohols from } \\
\text { lignocellulosic feedstock through chemical } \\
\text { and biological processes }\end{array}$ & $\begin{array}{l}\text { Preparation of feedstock, } \\
\text { enzymes }\end{array}$ & $\begin{array}{l}\text { Demonstration } \\
\text { stage }\end{array}$ & $\begin{array}{l}20-40 / \\
100-200\end{array}$ \\
\hline 6 & $\begin{array}{l}\text { Hydrocarbons (e.g. diesel and jet fuel) } \\
\text { through biological and/or chemical synthesis } \\
\text { from biomass containing carbohydrates }\end{array}$ & $\begin{array}{l}\text { Microorganisms, catalyst } \\
\text { performance, bio-processing }\end{array}$ & $\begin{array}{l}\text { Demonstration } \\
\text { stage }\end{array}$ & $\begin{array}{l}5-20 / \\
50-100\end{array}$ \\
\hline 7 & $\begin{array}{l}\text { Bioenergy carriers produced by micro- } \\
\text { organisms (algae, bacteria) from } \mathrm{CO}_{2} \text { and } \\
\text { sunlight }\end{array}$ & $\begin{array}{l}\text { Selection of strains, process } \\
\text { design, water treatment, scale } \\
\text { up }\end{array}$ & Pilot stage & $\begin{array}{l}20-40 / \\
100-300\end{array}$ \\
\hline
\end{tabular}

* It should be noted that because demonstration and first commercial plants are by definition "first ever built", the costs cannot be accurately estimated, until a basic design engineering study ( + or -30 percent estimate) or a detailed engineering study (+ or -10 percent estimate) have been performed. 